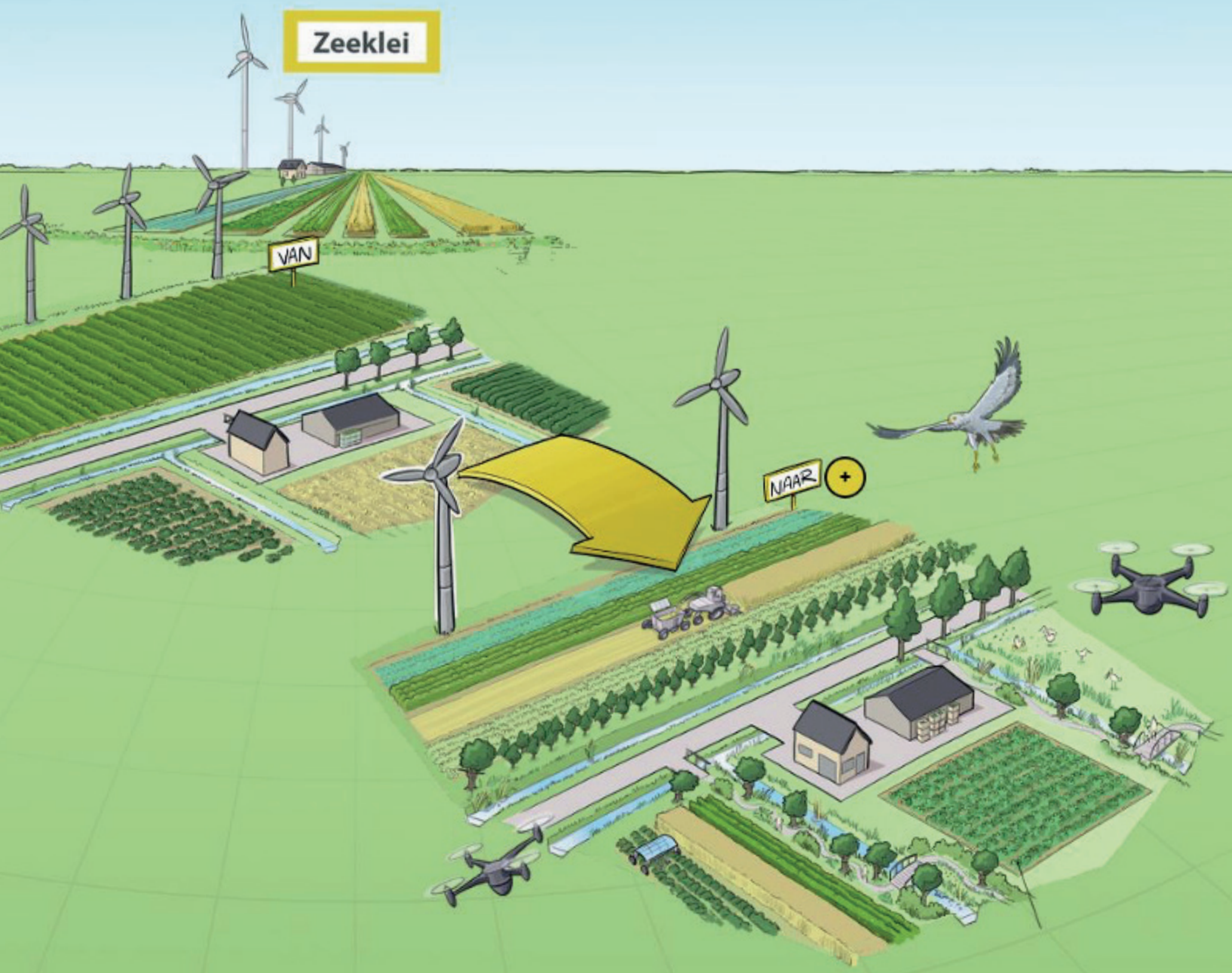

Ontwerp Boerderij van de Toekomst

WR is een onderdeel van Wageningen University \& Research, samenwerkingsverband tussen Wageningen University en de Stichting Wageningen Research. 


\section{Ontwerp Boerderij van de Toekomst}

Chris de Visser, Wijnand Sukkel, Corné Kempenaar, Tamme van der Wal, Pieter de Wolf, Andries Visser, Bert Smit, Herman Schoorlemmer, Maureen Schoutsen, Koen Klompe, Bram Veldhuisen, Isabella Selin-Noren, Chris van Dijk, Stefan Hol, Marcel van der Voort, Bas Janssens ${ }^{1}$

1 Wageningen University \& Research

WR is een onderdeel van Wageningen University \& Research, samenwerkingsverband tussen Wageningen University en de Stichting Wageningen Research.

Wageningen, februari 2020

Rapport WPR-823 
Visser, C. de, Sukkel, W., Kempenaar, C. Wal, T. van der, Wolf, P. de, Visser, A., Smit, B., Schoorlemmer, H., Schoutsen, M. Klompe, K., Veldhuisen, B., Selin-Noren, I., Dijk, C. van, Hol, S., Voort, M. van der, Janssens, B., 2020. Ontwerp Boerderij van de Toekomst; ontwerp. Wageningen Research, Rapport WPR-823.

Dit rapport is gratis te downloaden op https://doi.org/10.18174/520716.

(C) 2020 Wageningen, Stichting Wageningen Research, Wageningen Plant Research, Business unit Open Teelten, Postbus 430, 8200 AK Lelystad; T 03202911 11; www.wur.nl/plant-research

KvK: 09098104 te Arnhem

VAT NL no. 8113.83.696.B07

Stichting Wageningen Research. Alle rechten voorbehouden. Niets uit deze uitgave mag worden verveelvoudigd, opgeslagen in een geautomatiseerd gegevensbestand, of openbaar gemaakt, in enige vorm of op enige wijze, hetzij elektronisch, mechanisch, door fotokopieën, opnamen of enige andere manier zonder voorafgaande schriftelijke toestemming van Stichting Wageningen Research.

Stichting Wageningen Research is niet aansprakelijk voor eventuele schadelijke gevolgen die kunnen ontstaan bij gebruik van gegevens uit deze uitgave.

Rapport WPR-823 


\section{Inhoud}

$\begin{array}{lr}\text { Samenvatting } & \mathbf{5}\end{array}$

$\begin{array}{llr}1 & \text { Aanleiding } & 7\end{array}$

$2 \quad$ Visie, missie en strategie $\quad 9$

2.1 Kringlooplandbouw $\quad 9$

2.2 Vormgeving BvdT $\quad 9$

$\begin{array}{lll}2.3 & \text { Doelen BvdT } & 10\end{array}$

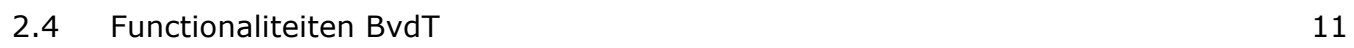

$\begin{array}{lrr}3 & \text { Locatiekeuze } & 13\end{array}$

$\begin{array}{llr}4 & \text { Proces van ontwerp } & 15\end{array}$

$\begin{array}{llr}5 & \text { Ontwerp BvdT } & 17\end{array}$

$\begin{array}{llr}5.1 & \text { Governance } & 17\end{array}$

$\begin{array}{ll}5.2 & \text { Netwerk en interactie } \\ 5.3 & 19\end{array}$

$\begin{array}{lll}5.3 & \text { Ecologische infrastructuur } & 20\end{array}$

$\begin{array}{lll}5.4 & \text { Agronomie } & 23\end{array}$

5.5 Mechanisatie $\quad 26$

$\begin{array}{lll}5.6 & \text { Data en precisietechnologie } & 31\end{array}$

$\begin{array}{lll}5.7 & \text { Energie } & 35\end{array}$

$\begin{array}{lll}5.8 & \text { Reststromen en circulatie } & 36\end{array}$

$\begin{array}{lll}5.9 & \text { Verdienmodellen } & 40\end{array}$

$\begin{array}{llr}\text { Bijlage } 1 & \text { Betrokken organisaties } & 45\end{array}$ 


\section{Samenvatting}

Het voorliggende ontwerp van de Boerderij van de Toekomst (BvdT) is een faciliteit die bij kan dragen aan de transitie van kringlooplandbouw in Nederland. Dit kan de BvdT doen doordat het enerzijds een faciliteit biedt voor de ontwikkeling van innovaties door technologiebedrijven en een onderzoeksplatform voor aanpalende onderzoeksprojecten en anderzijds doordat het laat zien hoe je in de landbouw invulling kan geven aan huidige uitdagingen op basis van kringlooplandbouw. Daarnaast biedt de BvdT een platform waaromheen een netwerk van stakeholders gebouwd kan worden waarin kennis en ervaringen uitgewisseld worden om zodoende kringlooplandbouw te verrijken en uit te rollen.

De BvdT laat kringlooplandbouw zien zoals die in staat is om in harmonie met mens, maatschappij, natuur en landschap te functioneren en die de boer een gezond inkomen biedt gericht op langdurige continuïteit. Daartoe moet de BvdT voldoen aan doelen op gebied van herstel van natuurlijke hulpbronnen zoals bodem, water en functionele biodiversiteit. Deze vorm van landbouw dient klimaatrobuust te zijn, een weerbaar systeem op te leveren dat in staat is tot minimaal gebruik van gewasbeschermingsmiddelen en minimaal gebruik te maken van kunstmest en in plaats daarvan maximaal gebruik te maken van circulaire stromen om planten- en bodemvoeding mogelijk te maken. De BvdT moet ook kunnen functioneren op basis van duurzame energie zonder gebruik te maken van fossiele energiebronnen.

Het voorliggende ontwerp gaat uit van een akkerbouwbedrijf dat interacteert met een veebedrijf. Het akkerbouwbedrijf bevindt zich in Flevoland. Echter, voor de vorming van kringlooplandbouw zijn ook in andere regio's en sectoren dit soort initiatieven nodig.

Om de rol in de transitie naar kringlooplandbouw te spelen, is het van belang dat het concept van de BvdT uiteindelijk in eigendom komt van de stakeholders die ook - beter dan WUR en LNV alleen - in staat zijn om dit concept te vestigen in de praktijk. In eerste instantie wordt een Programmaraad voorgesteld waarin stakeholder vertegenwoordigd zijn en die de BvdT aanstuurt en die een rol heeft in de transitie. Later kan een stichting- of verenigingsvorm gekozen worden.

De BvdT kent een kraamkamer waarin innovaties die nog meer aan het begin van hun ontwikkeling staan, getest en verbeterd kunnen worden. Daarnaast kent de BvdT een FieldLab waar op semipraktijkschaal (25 ha) de ontworpen vorm van kringlooplandbouw gedemonstreerd kan worden.

In dit voorliggende ontwerp komen diverse aspecten aan de orde die in samenwerking met een groep van stakeholders zijn uitgewerkt tot allereerst een set van aspect gebonden ontwerpen en later een integraal ontwerp. De aspecten betreffen:

- Agroecologie: het gaat hierbij om een combinatie van gewasdiversiteit (op basis van strokenteelt), onbereden rijpaden (met daarbij horende mechanisatie) en een ecologische infrastructuur die enerzijds de functionele biodiversiteit ondersteunt en anderzijds een verbinding vormt met de ecologische structuur buiten de BvdT die aansluit op de ecologische hoofdstructuur.

- Technologie op basis van datacollectie, algoritmen, kunstmatige intelligentie, databeheer en connectiviteit de BvdT in staat stelt om met lichte, autonome voertuigen te opereren, preventief en tijdig ingrijpen - indien nodig - mogelijk te maken op basis van een uitgekiend monitoringsprogramma (sensoren) en variabel doseren.

- Energietechnologie die de BvdT in staat stelt fossiele energie in te ruilen voor duurzame energie.

- Een circulariteitsontwerp dat uitgaat van de eigen productie en de kringloop van nutriënten zoveel als mogelijk is kan sluiten.

- Verdienmodellen die de voorlopers in staat stelt om te schakelen zonder verlies van inkomen.

Op de BvdT worden bovenstaande ontwerpen integraal toegepast zodat een kraamkamer en een FieldLab ontstaan waarmee ontwikkeling, testen en demonstratie van innovaties mogelijk zijn in de context van kringlooplandbouw. 
Om de BvdT in 2020 al te laten functioneren, zijn al de eerste maatregelen genomen. Immers het groeiseizoen 2020 is al in de late herfst van 2019 gestart. Om de opzet en uitvoering van de BvdT voor te bereiden is een projectplan in ontwikkeling waarin keuzes worden gemaakt die én passen binnen het hier beschreven ontwerp én financieel haalbaar zijn. 


\section{Aanleiding}

De afgelopen decennia heeft de Europese landbouw zich ontwikkeld als een 'gewone' economische bedrijfstak, die opereert in een vrije markt. De Nederlandse landbouw heeft een sterke handelspositie ontwikkeld, vanuit een hoogwaardige productieomgeving (klimaat, bodem, kennis). Echter, de hoge kosten van grond en arbeid hebben bijgedragen aan intensivering, specialisatie en schaalvergroting. Dit heeft op zijn beurt een wissel getrokken op de ecologische en maatschappelijke omgeving (Wolf et al, 2019). Dat leidt tot toenemende kosten voor de landbouw door strengere voorwaarden aan de productie, waardoor het steeds lastiger om de competitie met andere wereldmarktspelers aan te gaan. De uitdagingen zijn dus groot: klimaatverandering, eindige hulpbronnen, verlies van biodiversiteit, ecologische en maatschappelijke doelen, de groeiende kloof tussen boer en burger en toenemende concurrentie met andere spelers op de wereldmarkt. De European Green Deal benoemt deze problemen ook (zie kader) en zal in 2020 met een "Farm to Fork Strategy" komen als beleidsreactie op deze situatie.

In de kringloop hebben we te maken met nationaal overschot op de fosfaatbalans, wat grotendeels verloren gaat via de consument/stad. De transitie naar een circulair agro-food systeem spitst zich in Nederland ook steeds meer toe op de verhouding tussen import en export, de verhouding tussen plantaardige en dierlijke productie en het menselijke lek in de kringloop. Het wordt steeds duidelijker dat een oplossing niet te vinden is in de continuering van het huidige systeem, maar meer in een verandering daarvan zoals ook de LNV visie op kringlooplandbouw aangeeft (zie kader). Deze transitie gaat verder dan een verandering in de primaire sector, maar omvat de hele agro-food sector, de consument en Uit de European Green Deal, November 2019 Food production still results in air, water and soil pollution, contributes to the loss of biodiversity and climate change, and consumes excessive amounts of natural resources, while an important part of food is wasted.

Uit de visie van LNV op kringlooplandbouw: Het moet dus anders: van voortdurende verlaging van de kostprijs van producten naar voortdurende verlaging van het verbruik van grondstoffen. Die omschakeling is mogelijk. ook de context van beleid en markt. Tegelijk beginnen transities met niche-experimenten op kleine schaal.

Om de transitie naar kringlooplandbouw te accommoderen is dus een inspirerend voorbeeld nodig op bedrijfs- of regioniveau waarbinnen ook ruimte bestaat om te experimenteren, te leren en te demonstreren en zo perspectief voor verandering te laten zien. Dit voorbeeld, met name gericht op de boeren van de toekomst, moet een duidelijke trendbreuk met de huidige productiemethoden laten zien zonder dat de transitie onoverbrugbaar lijkt. In de sectoren is draagvlak voor een verandering naar een vorm van landbouw zonder de genoemde negatieve externaliteiten. Dat blijkt bijvoorbeeld uit het Actieplan Plantgezondheid van BO Akkerbouw dat een omslag voorstaat naar een weerbaar teeltsysteem dat een bijdrage levert aan vergroting van de biodiversiteit en vormgever is van een aantrekkelijk landschap. Dit voorstel beoogt dit toekomstperspectief voor in eerste instantie een akkerbouwbedrijf in kringloopverband in te kleuren en een streefbeeld neer te zetten: de Boerderij van de Toekomst, hierna af te korten als BvdT. 


\section{Visie, missie en strategie}

De centrale missie van de BvdT is om een belangrijke bijdrage te leveren aan de transitie naar kringlooplandbouw in Nederland. Deze bijdrage krijgt gestalte langs twee lijnen:

1. Laten zien hoe je in de landbouw invulling kan geven aan huidige uitdagingen (termijn 5-10 jaar) op basis van kringlooplandbouw met gebruik van innovaties die nog niet in de praktijk gebruikt worden.

2. Een faciliteit creëren zodat innovaties in de context van kringlooplandbouw effectief ontwikkeld en getest kunnen worden.

\subsection{Kringlooplandbouw}

De Kringlooplandbouw visie omvat alle belangrijke uitdagingen waar de landbouw momenteel voor staat. De landbouw moet meer in harmonie met mens, maatschappij, natuur en milieu komen. Emissies dienen substantieel verminderd te worden op basis van een herstel van bodemkwaliteit in al haar facetten (biologisch, chemisch, fysisch). Externe inputs moeten geminimaliseerd worden zoals gebruik van gewasbeschermingsmiddelen, kunstmest en fossiele energie. Biodiversiteit in het cultuurlandschap dient hersteld te worden mede om natuurontwikkeling in natuurgebieden te ondersteunen. Daarnaast staat de landbouw voor de opgave om zich aan te passen aan het veranderend klimaat.

Kringlooplandbouw is een vorm van landbouw gebaseerd op agroecologische principes die zal leiden tot herstel van biodiversiteit op het platteland en vraagt daarmee ook een landschappelijk inbedding in ecologische structuren en verbinding met natuurgebieden. En dat kan alleen als de boer een eerlijke prijs voor zijn of haar producten krijgt. Deze vorm van landbouw is NIET een terugkeer naar de tijd van Ot en Sien. Het is een vorm van landbouw die steunt op hoogwaardige technologie, datamanagement en robotica: autonome lichte voertuigen, sensoren, connectiviteit en algoritmes moeten de agroecologische principes ondersteunen en versterken. Agroecologie en technologische vernieuwing gaan daarmee zo veel mogelijk hand in hand. Dit voorstel heeft een accent op akkerbouwmatige plantaardige productie maar circulariteit vereist dat de BvdT interacteert met andere sectoren en met afzetketens om hergebruik van restromen maximaal te realiseren. Kringlooplandbouw streeft naar vermindering van externe inputs en daarom moet ook de energievoorziening van de BvdT zoveel mogelijk gebaseerd zijn op eigen productie van duurzame energie.

\subsection{Vormgeving BvdT}

De BvdT voert geen zelf onderzoek uit maar zal wel onderzoek agenderen. Dat kan gaan over systeemonderzoek of over aspectenonderzoek dat een bouwsteen vormt voor verbetering van kringlooplandbouw. De BvdT biedt conform de missie hiertoe wel faciliteiten aan. De BvdT zal over drie typen van faciliteiten beschikken:

1. Een FieldLab in Lelystad, waar innovaties in gevorderde stadia van ontwikkeling gedemonstreerd kunnen worden in een bedrijfssysteemcontext op semi-praktijkschaal. Het Fieldlab bestaat uit een akkerbouwbedrijf van 25 ha (in verbinding met een veehouderijbedrijf in de buurt) en een faciliteit voor opwekking van duurzame energie en ontwikkeling en demonstratie van valorisatie van reststromen (zoals humane stromen).

2. Een innovatieprogramma, wat als een kraamkamer functioneert waarbij innovaties in vroegere stadia van ontwikkeling verder vorm kunnen krijgen. Dit innovatieprogramma vormt ook een 
verbinding met aanpalende onderzoeksprogramma's, zoals de Proeftuin voor Agro-ecologie en technologie, Nationale Proeftuin Precisielandbouw (NPPL), KennisBasisonderzoek, Topsectoren, BO-Akkerbouw, NWO, NWA, etc.

3. Een platform waarin stakeholders betrokken worden bij de transitie naar kringlooplandbouw, via communicatie- en netwerkactiviteiten, vanuit een gerichte transitiemanagementstrategie. Deze faciliteiten maken van de BvdT ook een geschikt platform waar interactie met stakeholders kan ontstaan. Rondom de BvdT dient een netwerk gebouwd te worden waarin kennis uitgewisseld wordt ten behoeve van de ontwikkeling van en transitie naar kringlooplandbouw in de praktijk.

Met name in het FieldLab zullen innovaties opgenomen worden die de praktijk nog niet doet vanwege kosten, schaal, regelgeving, onbekendheid, risicoperceptie maar die wel bijdragen aan de doelstellingen en uitdagingen van de BvdT. Voor technologische innovaties geldt dat ze aan het begin van hun marktintroductie te duur en te complex zijn, maar bij bredere toepassing ook goedkoper worden en eenvoudiger toepasbaar. Voor andere innovatieve concepten, zoals geïntegreerde gewasbescherming, geldt dat ze vaak vooruitlopen op een context waarin bijv. de huidige gewasbeschermingsmiddelen niet meer effectief of toegelaten zijn. Voor andere innovaties geldt dat het verdienmodel nog niet bestaat, zoals concepten waarin landbouw ecologische of maatschappelijke diensten levert.

De BvdT zal dus vooruitlopen op de huidige praktijk, maar wel met het besef dat het gaat om innovatieve oplossingen voor reële uitdagingen voor de boeren van de toekomst. Daarin worden pioniers in de praktijk nauw betrokken: bedrijven die meer risicobereidheid en innovatiekracht hebben dan veel van hun collega's. Sommige pioniers lopen vooruit op een specifiek thema, zoals precisielandbouw, bemesting of bodembeheer. Andere bedrijven pionieren met nieuwe verdienmodellen en ketenconcepten. De BvdT is echter in staat om op al deze thema's integraal voorop te lopen. Het is daarom van groot belang deze pioniers nauw bij de BvdT te betrekken. Immers, ervaringen van boeren zijn hebben binnen de BvdT minstens zo veel gewicht als technische resultaten uit onderzoek van bedrijven en kennisinstellingen.

\subsection{Doelen BvdT}

De BvdT zal meerdere doelen moeten dienen:

- Herstel en onderhoud van natuurlijke hulpbronnen zoals bodem, water en biodiversiteit.

- Een klimaatrobuust productiesysteem (wateroverlast en droogte).

- Een weerbaar teeltsysteem waarin ziekten en plagen minder kans krijgen en gebruik van gewasbeschermingsmiddelen zoveel mogelijk voorkomen wordt. Nagenoeg zonder emissies naar het milieu en zonder residuen.

- Minimaal gebruik van kunstmest.

- Herstel van de natuurwaarden in de landbouw (insecten, vogels, kleine zoogdieren)

- Energie neutraal tot energie producerend, maximaal gebruik makend van reststromen en per saldo $\mathrm{CO} 2$ equivalenten vastleggend.

- Verbeterde sociaal-economische positie van boeren (arbeid, inkomen).

Het voorliggende ontwerp heeft aspecten in zich waarmee tegemoet kan komen aan bovenstaande doelstellingen. Biodiversiteit wordt bevorderd door gewasdiversiteit, een ecologische infrastructuur en een aandacht voor bodemkwaliteit via grondbewerking, rijpadensysteem en aanvoer organische stof. De verhoogde bodemkwaliteit leidt ook tto een klimaatrobuustheid: afvoer van te veel water en verhoging van het waterhoudend vermogen. Het maximale gebruik van circulaire organische stromen moet het gebruik van kunstmest minimaliseren. De verhoogde functionele agrobiodiversiteit via gewasdiversiteit, strokenteelt, beter bodembeheer en ecologische structuur in het perceel, draagt in combinatie met een programma van monitoring van ziekten bij aan een sterke en substantiële vermindering van het gebruik van gewasbeschermingsmiddelen terwijl bij de keuze van middelen goed gekeken zal worden naar het effect op milieu. Naast het gebruik van kunstmest en gewasbeschermingsmiddelen zal ook de externe input van energie worden aangepakt. Dit zal gebeuren op basis van hernieuwbare energiebronnen en de opslag hiervan via waterstof. 
Bovenstaande doelen zijn nog niet SMART. Dat is met opzet zo gekozen om zodoende stakeholders die dicht bij de BvdT betrokken worden mee te nemen in de doelstellingen voor de termijn van 4 jaar en de monitoring daarop af te stemmen.

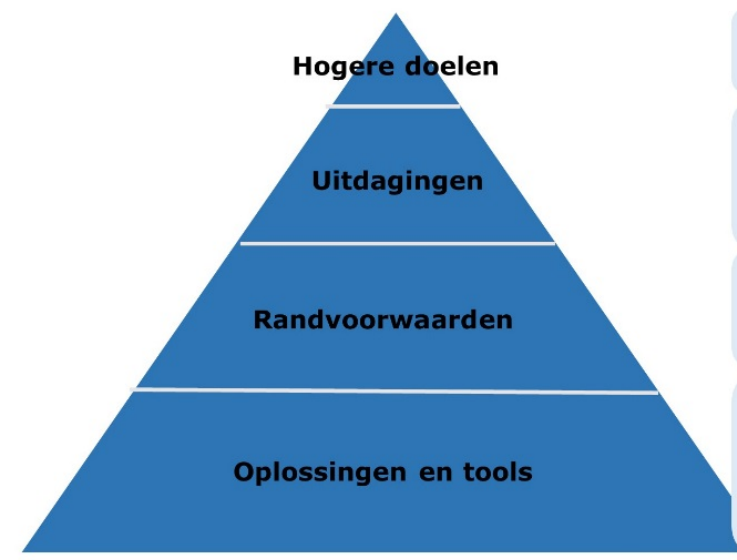

Herstel hulpbronnen, herstel biodiversiteit, klimaat, voedsel, economie

Bodemverdichting, bodemgezondheid, emissies, energietransitie, koolstofvastlegging, inkomenspositie boeren, kringloopsluiting, verhouding landbouw-natuur

systeeminnovatie; technologie is dienend aan ecologie, vermindering inputs en maximalisatie circulariteit

Bodemkwaliteit, gewasdiversiteit, ecologische infrastructuur, onbereden teeltbedden, robotisering, Al, data, connectiviteit, benutting reststromen, benutting duurzame energie, verdienmodellen

\section{Figuur 2.1 Doelpiramide.}

In figuur 2.1 is de doelpiramide van de BvdT afgebeeld om duidelijk te maken hoe uiteindelijke oplossingen en tools gekozen moeten worden op basis van de hierboven genoemde doelstelling, de uitdagingen waar de (in dit geval) akkerbouwmatige plantaardige productie mee te maken heeft en de randvoorwaarden waarbinnen oplossingen worden gekozen. De uiteindelijke oplossingen dienen geïmplementeerd te worden indien zij bijdrage aan de doelstellingen, een antwoord geven aan de uitdagingen van de akkerbouw en voldoen aan de randvoorwaarden (vaak ontleent aan kringlooplandbouw) die daarvoor gesteld kunnen worden. In volgende hoofdstukken zullen de oplossingen die in dit ontwerp zijn opgenomen de revue passeren.

\subsection{Functionaliteiten BvdT}

De BvdT wil haar missie volbrengen en haar doelen bereiken via een aantal functionaliteiten die ook hun haakjes hebben bij de vormgeving en het ontwerp.

De BvdT wil technologieën (in brede zin) die nodig zijn voor kringlooplandbouw helpen ontwikkelen door de faciliteiten FieldLab en kraamkamer. Deze ondersteuning geeft de BvdT in het volledige traject van het experimenteren in de eerste fasen van de vormgeving van de technologieën, via het testen van prototypes tot en met het demonstreren van de eerste fase van volwassenheid. Daarnaast is het van groot belang dat de BvdT een platform is waar kennis en ervaringen over kringlooplandbouw worden gedeeld tussen alle betrokken stakeholders. Tenslotte zal de BvdT ook interacteren met het groene onderwijs dat de boeren en medewerkers van de toekomst opleidt. De governance moet deze functionaliteiten borgen terwijl de BvdT de daartoe geëigende plek in het netwerk (ecosysteem) moet gaan innemen. 


\section{Locatiekeuze}

Als locatie is gekozen voor het proefbedrijf van Wageningen University \& Research te Lelystad. Dat heeft meerdere redenen:

- Er ligt al een experimenteerruimte voor landbouw (of: kraamkamer) gebaseerd op agroecologische principes met een aantal langjarige experimenten: strokenteelt, niet-kerende grondbewerking, agroforestry, integrale aanpak gewasgezondheid.

- Met TNO zal een faciliteit op gebied van duurzame energie worden opgezet waar opslag van duurzame energie een belangrijk onderdeel is (accu's en waterstof productie).

- Het akkerbouwbedrijf produceert veel wind- en zonne-energie.

- Er is een gebouw beschikbaar dat kan dienen als ontvangst- en expositieruimte.

- De beheerders hebben de ambitie geformuleerd om allereerst het erf gasloos te maken en waterstof te produceren op basis van zonne-energie ten vervanging van gebruik van fossiele brandstof op het erf (drogen producten, logistiek). In tweede aanleg is de doelstelling geformuleerd om alle dieselverbruik op het 800 ha grote bedrijf te vervangen door elektriciteit en waterstof.

- Er zal een kavel van circa 25 ha ingericht worden volgens agroecologische principes dat beheerd gaat worden als akkerbouwbedrijf. Dit wordt het FieldLab waar innovaties getest en gedemonstreerd kunnen worden in een setting van de toekomstige landbouw.

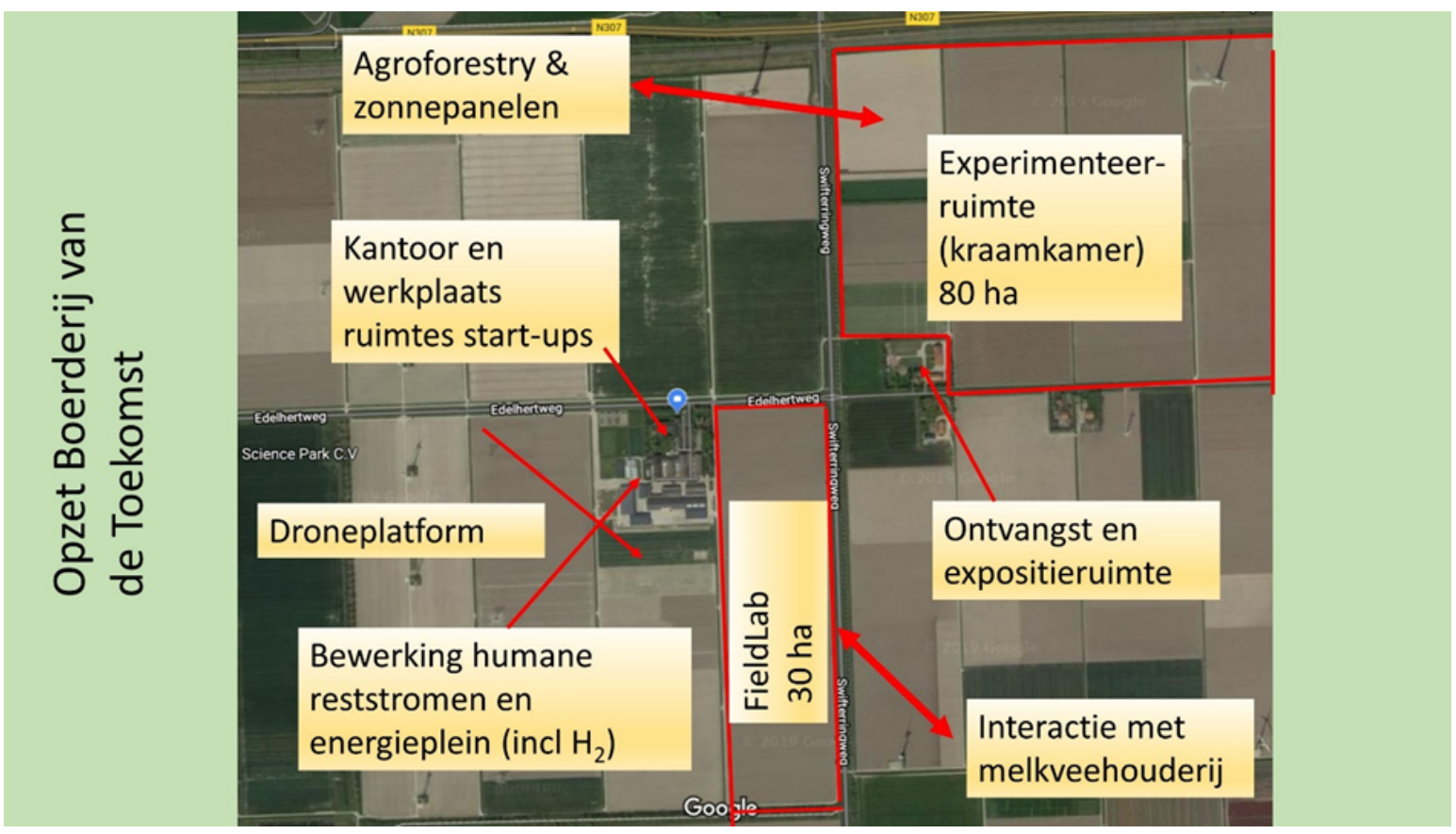

Figuur 3.1 Plattegrond faciliteiten. 


\section{Proces van ontwerp}

Deze rapportage geeft het ontwerp weer van de BvdT. Dit ontwerp moet een serie aspecten integreren die ieder afzonderlijk individuele expertises en kijkrichtingen vereisen. Om die reden is er voor gekozen om allereerst per ontwerp aan de gang te gaan en daarvoor separate werkgroepen met trekkers en secretarissen in te stellen. De werkgroepen staan in Tabel 1 genoemd en de betrokken stakeholders staan per deelontwerp opgesomd in Bijlage 1.

Tabel 1 Ontwerpgroepen, trekkers en secretarissen.

\begin{tabular}{lll} 
Werkgroep met ontwerpaspect & Werkgroeptrekker & Secretaris \\
Netwerk, samenwerking (incl onderwijs), & Chris de Visser & Maureen Schoutsen \\
governance, financiering & & Koen Klompe \\
\hline $\begin{array}{l}\text { Agroecologie } \\
\text { Precisielandbouw, mechanisatie, data }\end{array}$ & Wijnand Sukkel & Chris van Dijk \\
infrastructuur, connectiviteit & & Stefan Hol \\
\hline Gebruik reststromen, kringlopen & Pieter de Wolf & Marcel van der Voort \\
\hline $\begin{array}{l}\text { Energieproductie en gebruik } \\
\text { Nieuwe verdienmodellen en korte ketens }\end{array}$ & Bert Smit & Bas Janssens \\
\hline
\end{tabular}

Het project is volgens een strak tijdschema aan de gang gegaan (Tabel 2)

Tabel 2 Planning ontwerpfase BvdT.

\begin{tabular}{|c|c|}
\hline Datum & Milestone / activiteit \\
\hline $9 / 10 / 19$ & Samenstelling werkgroepen + vaststellen opdracht en proces \\
\hline \multirow[t]{2}{*}{$21 / 10 / 19$} & Kick-off met trekkers van werkgroepen (08:30-10:15 in Lelystad) \\
\hline & Werkgroepen aan de slag \\
\hline $27 / 11 / 19$ & Werkgroeptrekkers sturen mid-term rapportage naar stuurgroep \\
\hline \multirow[t]{2}{*}{$2 / 12 / 19$} & $\begin{array}{l}\text { Mid-term overleg stuurgroep en werkgroepen plus LNV: uitwisseling, afstemming, correctie: 09:00-12:00 } \\
\text { uur in Lelystad }\end{array}$ \\
\hline & Werkgroepen passen mid-term rapportage aan en maken het definitief \\
\hline \multirow[t]{2}{*}{ 20/12/19 } & Werkgroepen sturen ontwerprapportage op. \\
\hline & Stuurgroep maakt concept geïntegreerde rapportage \\
\hline \multirow[t]{2}{*}{$7 / 1 / 20$} & Bespreking concept integraal ontwerp met werkgroepen en stuurgroep: 09:00-12:00 uur in Lelystad \\
\hline & Stuurgroep stelt integraal ontwerp bij \\
\hline \multirow[t]{2}{*}{$15 / 1 / 20$} & Bespreking concept integraal ontwerp met externe stakeholders: 10:00-13:00 uur (met lunch) in Lelystad \\
\hline & Stuurgroep maakt finaal integraal ontwerp plus detail projectplan BvdT \\
\hline \multirow[t]{2}{*}{$31 / 1 / 20$} & Integraal ontwerp en projectplan BvdT worden opgeleverd \\
\hline & Uitrol activiteiten BvdT \\
\hline
\end{tabular}

Op 2 december hebben de ontwerpgroepen hun tussenresultaten gedeeld en besproken. Daarbij zijn enkele technische dilemma's naar voren gekomen (strokenbreedte op het Fieldlab en inpassing van zonne-energie) die in de weken daarna geleid hebben tot een keuze. Daarmee is de eerste aanzet gegeven tot een integraal ontwerp.

Deze rapportage is het concept integraal ontwerp zoals dat op 15 januari 2020 met stakeholders moet worden besproken. 


\section{Ontwerp BvdT}

Het ontwerp voor de BvdT is opgebouwd uit een aantal, op elkaar afgestemde, deelontwerpen waarin oplossingen en tools opgenomen zijn die tegemoet komen aan de hogere doelen, de uitdagingen en de randvoorwaarden. Samen laten zij zien hoe de BvdT een streefbeeld laat zien van een toekomstige akkerbouw bedrijf dat in harmonie met de leefomgeving produceert en waarop geëxperimenteerd, gedemonstreerd, kennis gedeeld en geleerd kan worden zodat het inspirerend voorbeeld weerklank vindt in de praktijk.

\subsection{Governance}

De missie van de BvdT wil een duidelijke bijdrage leveren aan de transitie naar kringlooplandbouw. Dit vergt de betrokkenheid van stakeholders die deze transitie kunnen en moeten ondersteunen om het tot een succes te maken. De governance structuur van de BvdT moet dit tot uiting brengen.

Bij de keuze van een governancemodel zijn meerdere aspecten van belang:

- Taakopvatting BvdT. Het type taak kan grenzen stellen aan rechts- of organisatievorm (of sluit deze uit).

- Motieven deelnemers BvdT. Het motief waarom deelgenomen wordt, bepaalt de gewenste mate van zeggenschap.

- Waarden deelnemers BvdT. Opvattingen van de deelnemers over de gewenste en benodigde organisatievorm van de organisatie (o.a. licht/zwaar).

- Consequenties model. Deze moeten voor de deelnemers aanvaardbaar zijn.

- Implementatie. Aanpak, doorlooptijd, en inspanningen (financieel en personeel) moeten voor de deelnemers aanvaardbaar zijn.

De gewenste mate van zeggenschap van stakeholders, zal in belangrijke mate ook bepalen welke vorm hiervoor het meest geschikt is. Deze zeggenschap kan ook in de tijd veranderen afhankelijk van de fase van ontwikkeling van de BvdT. Zo kan de aansturing in de ontwikkeling van de BvdT (dus de fase waarin gebouwd wordt aan de vorm en inhoud) een andere zijn dan in de fase dat het ontwerp nog niet uitgekristalliseerd is. De BvdT moet duidelijk op weg zijn om de doelstellingen te bereiken. Immers, de motieven van stakeholders om medezeggenschap te willen aanvaarden, moeten gevoed worden door resultaten.

Van de andere kant is het evident dat om tegemoet te komen aan de missie van de BvdT, dit initiatief niet alleen bij WUR en LNV kan liggen. Het zal een sterke en brede basis in het veld moeten hebben.

Op basis van bovenstaande afwegingen wordt het volgende model voorgesteld zoals afgebeeld in figuur 5.1 .

De programmaraad wordt samengesteld uit vertegenwoordigers van overheden, boerenorganisaties, NGO's, ketenpartijen, onderwijs, waterschap, landschapsbeheer en technologiebedrijven. Gestreefd wordt naar een groep met een omvang van 8-12 leden. Deze programmaraad heeft de volgende taken:

- Maakt de doelstellingen van de BvdT SMART.

- Toetst voortgang van de BvdT aan de doelstellingen.

- Stelt werkplan het daarop volgende jaar vast.

- Denkt na over rol in transitie en de daarbij horende organisatievorm met zeggenschap.

- Bevordert het ontstaan van soortgelijke initiatieven in andere sectoren en regio's. 


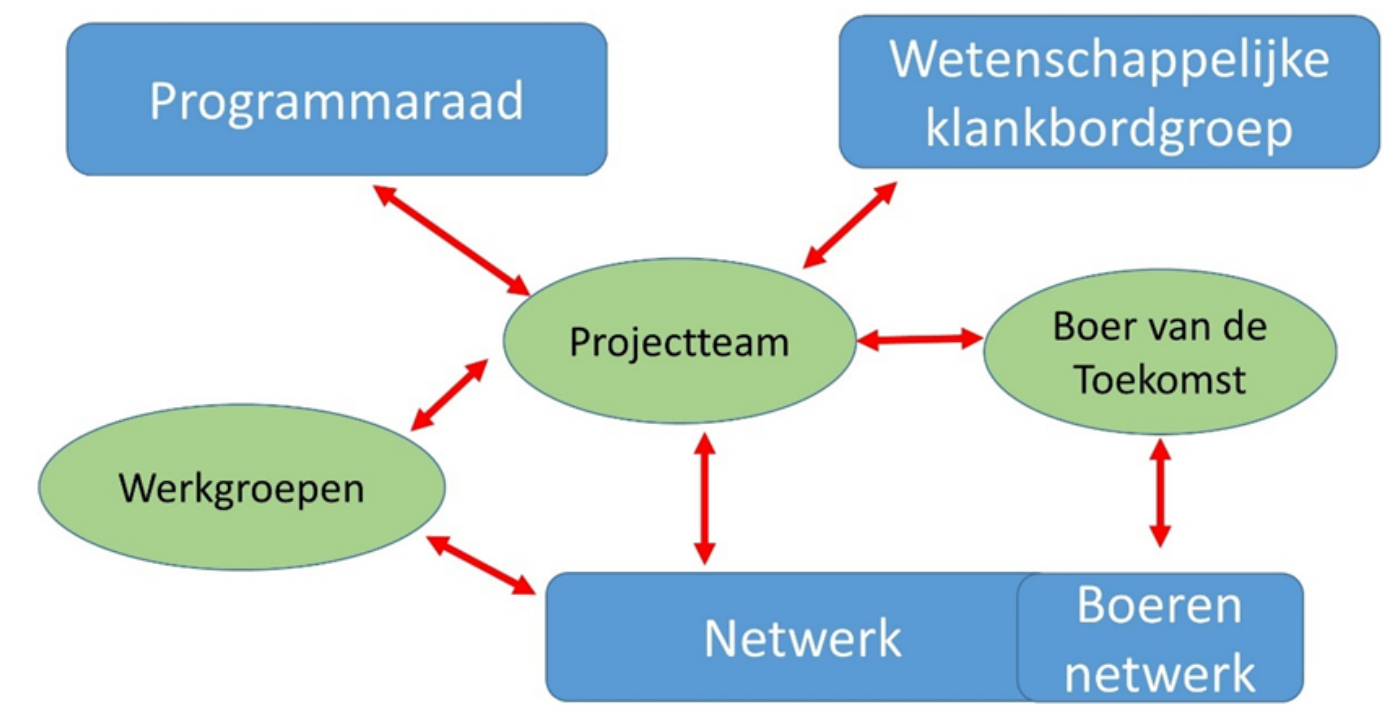

Figuur 5.1 Voorgestelde beheersstructuur van de BvdT in de aanvangsfase.

Het projectteam voorziet de programmaraad van de nodige informatie op basis waarvan zij haar werk kan doen. Het projectteam heeft de dagelijkse leiding over de BvdT en beheert de financiële middelen. De operationele leiding van het FieldLab wordt gevormd door een drietal jonge boerenzoons uit het gebied (in dienst van WUR Open Teelten). Zij zijn ook het eerste aanspreekpunt voor het boerennetwerk dat zich voornamelijk concentreert in Flevoland en zal bestaan uit boeren die met delen van kringlooplandbouw enige ervaring hebben dan wel daar sterk in geïnteresseerd zijn. Zij wisselen vooral praktische ervaring uit met elkaar om zodoende te leren over de wijze waarop technologieën toegepast kunnen worden. Deelaspecten van de BvdT zoals communicatie, transitie en interactie, monitoring, en innovatieprogramma worden vorm gegeven in werkgroepen. Deze werkgroepen zijn ingebed in het netwerk van relevante stakeholders waarin de genoemde functionaliteiten van de BvdT geborgd worden.

Het projectteam wordt bijgestaan door een wetenschappelijke klankbordgroep waarin de relatie met het wetenschappelijk onderzoek wordt gerealiseerd én waarin het gedachtengoed van dit ontwerp bewaakt wordt.

De werkgroep transitie, communicatie en interactie heeft een gewichtige taak om het netwerk te bouwen en betrokkenheid bij en bekendheid met de BvdT te vergroten bij alle geledingen die kunnen bijdragen aan het succes van de BvdT. Daarmee wordt ook bijgedragen aan de transitie naar kringlooplandbouw (stakeholdermanagement). Deze groep dient ook na te denken over voorstellen en de uitvoering daarvan (na goedkeuring door de programmaraad) om de transitie vorm te geven en transitiepaden te ontwikkelen.

De werkgroep monitoring dient ervoor te zorgen dat de metingen worden gedaan die uitsluitsel geven over de mate waarin de BvdT tegemoet komt aan de doelstellingen. Ook moet die werkgroep adviseren over bijstellingen die nodig zijn op basis van achterblijvende invulling van de doelstellingen zoals geconstateerd door de programmaraad. Deze werkgroep draagt ook zorg voor het onderhoud van de ecologische infrastructuur op en rondom de BvdT en houdt contact met organisaties die een belangrijke bijdrage aan die monitoring kunnen leveren. De werkgroep zal ook aanhaken op de ontwikkeling van de Key Performance Indicators (KPI) op gebied van milieu, biodiversiteit en klimaat zoals die in ontwikkeling zijn voor de landbouw ${ }^{1}$ en de Biodiversiteitsmonitor Akkerbouw.

\footnotetext{
${ }^{1}$ Erisman, J.W. * F. Verhoeven, 2019. Kringlooplandbouw in de praktijk. Analyse en aanbevelingen voor beleid. Publicatienummer 2019-013 LbP.
} 
De werkgroep Innovatieprogramma heeft als taak om verzoeken tot toegang van de faciliteiten van de BvdT ten behoeve van innovaties te begeleiden. Dit vraagt ook om interacties met programma's als NPPL. De groep dient daarnaast start-ups te faciliteren die met innovaties aan de slag zijn die dienend zijn aan de verbetering en optimalisering van kringlooplandbouw. Dit kan gaan om begeleiding in inhoudelijke of procesmatige zin. Ook moet de werkgroep adviseren of verzoeken tot toegang voldoende passen binnen de doelstellingen van de BvdT. Het projectteam neemt hierover de besluiten.

\subsection{Netwerk en interactie}

Dit aspect gaat vooral over de interactie tussen de BvdT en de stakeholders, de samenwerking met bedrijven en (kennis)instellingen en de governance. Om hieraan een invulling te geven is een aantal acties wenselijk:

- Maak een duidelijke pitch om BvdT neer te zetten: welk doel dient het en wat en hoe wil het dat bereiken. Definieer de USP's van de BvdT. Dit is handig in de communicatie én in het benaderen van partners. Het is van groot belang om de kernwaardes en de beoogde impact van de BvdT met buitenstaanders op een overtuigende manier te delen. Deze pitch moet uitnodigend zijn en een gedeeld en helder beeld vestigen zodat volgende acties hier logischerwijze inpassen.

- Maak een gelaagde samenwerkingsagenda: dit betekent dat per doelgroep en per project een specifieke benadering nodig is. Hierbij moet gedacht worden aan agrarisch ondernemers, erfbetreders, overheden, groene onderwijsinstellingen, bedrijven in de keten, NGO's en technologie bedrijven maar ook projecten die met innovaties bezig zijn die mogelijk passen in de kraamkamer of het FieldLab.

- Zet de boer van de toekomst in de interactie met de buitenwereld centraal. Het draait immers om de agrarisch ondernemer die dagelijks beslissingen moet nemen om de landbouw van de toekomst inhoud en gestalte te geven. Het gaat om zijn of haar motivatie, competenties, ondernemerschap en verdienvermogen. De BvdT kan alleen vorm krijgen met de Boer van de Toekomst.

- Denk na over een digital twin van de BvdT. Dit helpt om de uitrol van de nieuwe productiemethodes te realiseren.

- Werk de rol uit van de BvdT in de transitie naar kringlooplandbouw in Nederland (transitie). Hoe moet dit initiatief uiteindelijk leiden tot de vestiging van nieuwe vormen van landbouw die gezamenlijk aan de doelstellingen voldoen zoals verwoord in de visie van LNV over kringlooplandbouw? Welke bouwstenen (bijvoorbeeld verdienmodellen) en transitiepaden zijn hiervoor van belang?

- De BvdT dient - indien het succes wil hebben - eveneens een weg aan te geven die leidt naar een keten van de toekomst. Immers, de transitie naar kringlooplandbouw is een integrale inspanning van de gehele keten van veredelaar tot retailer en consument.

- Zorg met enige regelmaat voor een impactmeting bij boeren over de benadering van de BvdT: is er voldoende draagvlak en is er beweging bij boeren in de gewenste richting. Welke problemen ondervinden boeren hierbij en wat zijn succesvolle voorbeelden?

- Leg connecties met regionale organisaties om soortgelijke initiatieven in verschillende delen van het land mogelijk te maken. Op dit moment is hiervoor concrete interesse in Noorden Nederland en in Noord Brabant. Het is immers van groot belang voor het draagvlak voor en de vestiging van kringlooplandbouw in Nederland. Immers, de herkenbaarheid van kringlooplandbouw bij lokale boeren is gediend bij een streefbeeld in eigen omgeving.

- Leg connecties met andere sectoren (melkveehouderij, pluimveehouderij, varkenshouderij, glastuinbouw en fruitteelt) om na te gaan in hoeverre er draagvlak is om passende initiatieven te ontwikkelen om kringlooplandbouw te bevorderen.

- Een BvdT heeft onvoldoende waarde als er niet tegelijkertijd ingezet wordt op ontwikkeling van kennis en technologieën die ondersteunend zijn voor kringlooplandbouw. Het is daarom van belang om in overleg te gaan met subsidieverleners als NWO, RVO en LNV om beschikbare financiële instrumenten te laten aanhaken op de BvdT zodat innovaties ondersteund kunnen worden. Ook is het van belang om de steun die er is bij bedrijven in de keten voor kringlooplandbouw gestalte te geven en ze te betrekken bij de ontwikkelingen. 
Om deze reden is het verstandig om een groep van supporters of vrienden van de BvdT op te richten waarmee ook een aanvullende financiële injectie in het initiatief gestalte kan krijgen.

In figuur 5.2 is schematisch weergegeven hoe de BvdT in het innovatie ecosysteem van de kringlooplandbouw gepositioneerd is. Nieuwe kennis en inzichten die uit onderzoeksprogramma's komen, zullen ingepast gaan worden in de BvdT. Deze flow van informatie moet vanuit de BvdT gestalte krijgen en daarvoor is de wetenschappelijke klankbordgroep primair aan zet. Daarnaast zal de BvdT nauw contact moeten hebben met boeren zoals het eigen boerennetwerk maar ook andere boerennetwerken die functioneren zoals NPPL. Van daaruit kan ook opschaling in de praktijk vorm krijgen. De BvdT in Flevoland zal ook in een eigen netwerk van boerderijen van de Toekomst gaan functioneren (in andere regio's of andere sectoren).

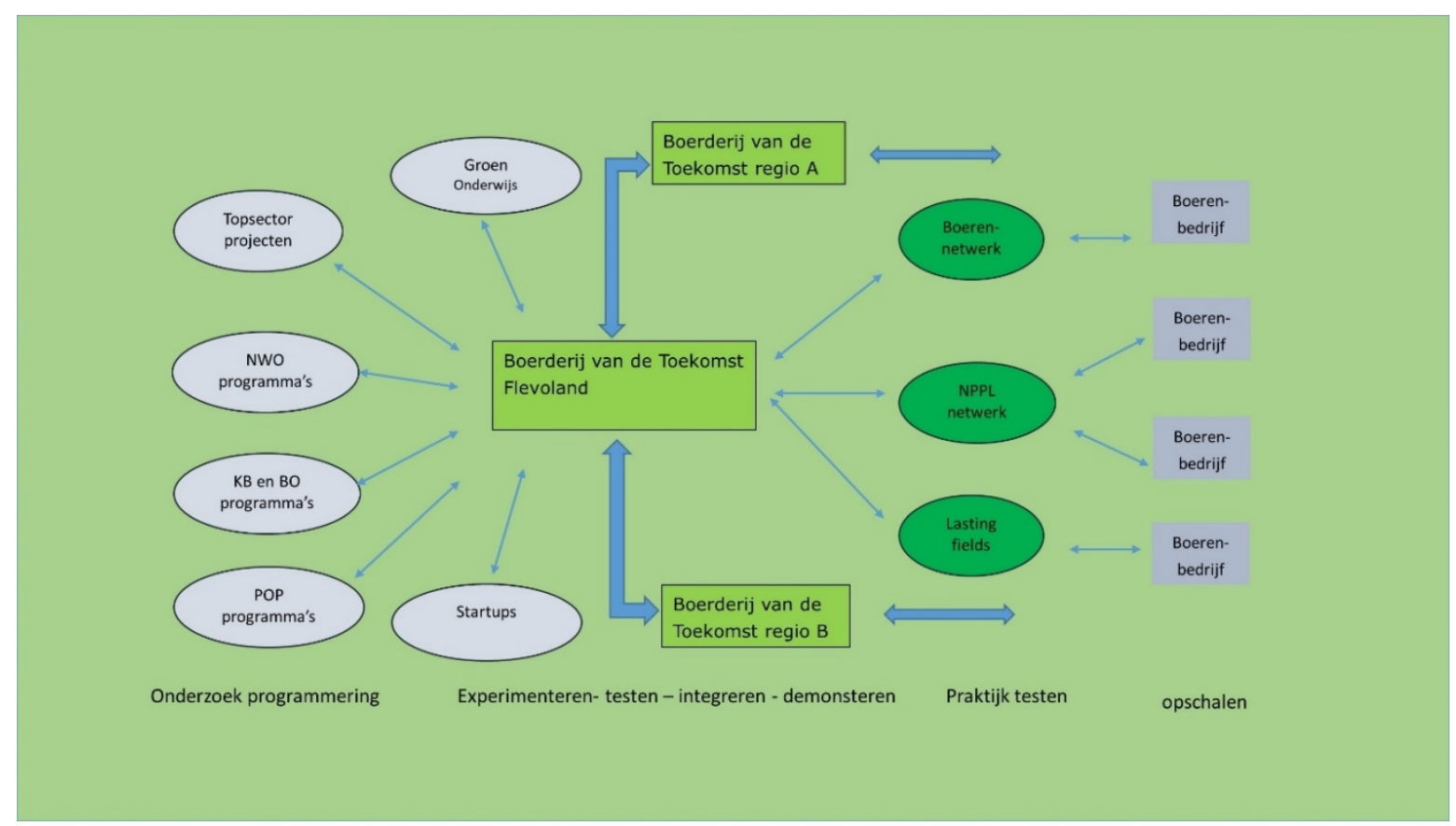

Figuur 5.2 Innovatie ecosysteem van de BvdT.

\subsection{Ecologische infrastructuur}

Om optimaal gebruik te maken van functionele agrobioversiteit en om de biodiversiteit op het platte land te herstellen, is een ecologische infrastructuur nodig die aansluiting vindt in het landschap. Het gaat hier om de niet-productie plantaardige/water structuren op en om de BvdT. Dit is inclusief bestaande houtwallen, sloten en wegbermen. Een aantal uitgangspunten is hiervoor opgesteld:

- Behalve aanleg is ook beheer integraal onderdeel van het plan. Immers, de structuren moeten hun beoogde functionaliteit ook in de tijd vestigen.

- Deze ecologische structuren moeten onderling zoveel mogelijk verbonden zijn om maximaal effect te sorteren.

- De maximum aaneengesloten veldbreedte van productiegewassen is $150 \mathrm{~m}$. Dit wil zeggen dat de maximum afstand tussen de ecologische structuren 150 meter is.

- De ecologische infrastructuur van de BvdT dient verbonden te worden met landschappelijke elementen rond de BvdT (hagen, boomrijen, wegbermen, slootkanten).

- Over aanleg en beheer van de ecologische structuren op de BvdT en de aansluiting hiervan op bestaande ecologische structuren is overleg nodig met de verantwoordelijk beheerders zoals gemeente, waterschap en provincie.

- Ook gewassen en bodem zijn dragers van de biodiversiteit in het landschap.

- Een toegenomen gewasdiversiteit op de productiegebieden alsmede een integraal bodembeheer maken onderdeel uit van het beheer dat gericht is om herstel van biodiversiteit. 
- Biodiversiteit bevorderende maatregelen en beheer mogen de productiefunctie van de BvdT zo min mogelijk belemmeren. Dit houdt in dat positieve interacties biodiversiteit gestimuleerd moeten worden en dat de negatieve interacties zoveel mogelijk voorkomen dienen te worden.

- Aanleg en beheer van de ecologische structuren mogen de functies van de cultuur elementen als sloten, kopakkers, rijpaden en wegbermen niet of zo weinig mogelijk belemmeren (zie ook overleg met gemeente, waterschap en provincie).

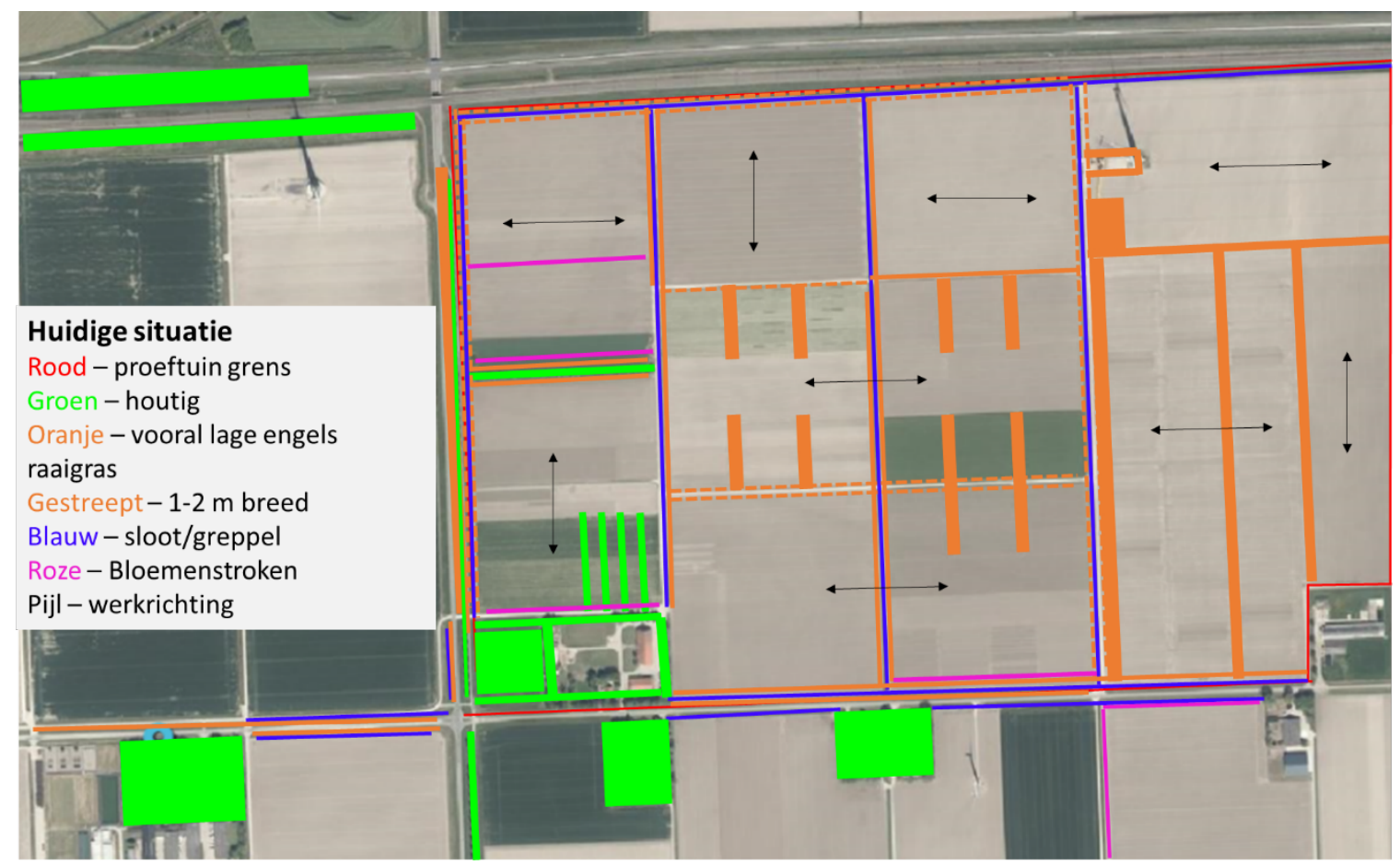

Figuur 5.3 Huidige situatie ecologische infrastructuur bvdT, gedeelte kraamkamer (ca. 80 ha).

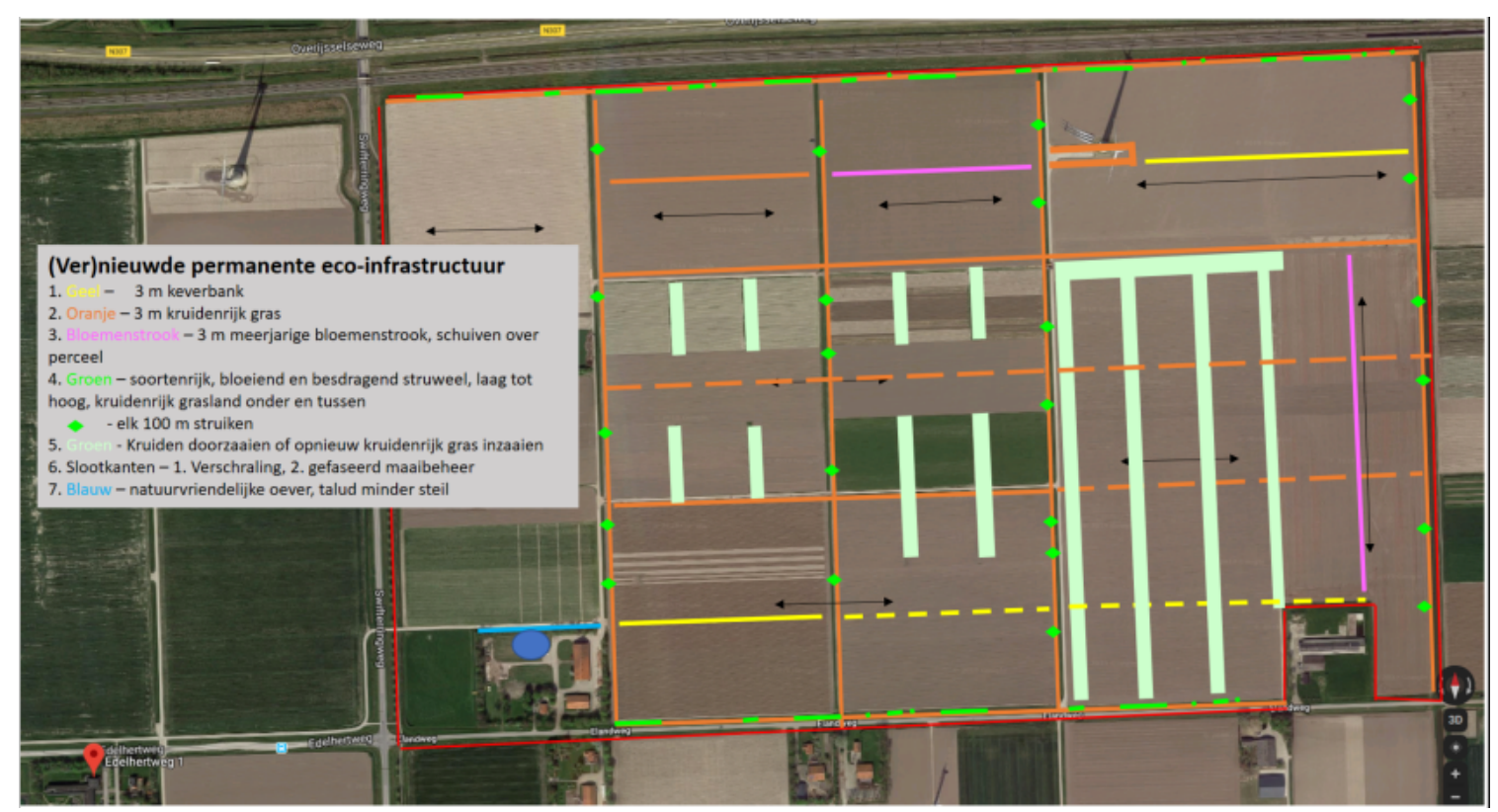

Figuur 5.4 Voorstel voor ontwerp ecologische infrastructuur, gedeelte kraamkamer (ca. 80 ha).

De aanwezige en aangepaste structuren op de BvdT staan weergegeven in de figuren 5.3 tot en met 5.6. De figuren hebben betrekking op twee onderdelen, de Kraamkamer en het FieldLab. 
In figuur 5.7 wordt de aansluiting op landschappelijke ecologische structuren aangegeven.

Kraamkamer en FieldLab raken elkaar op de kruising Swifterringweg-ElandwegEdelhertweg. Het Kraamkamer gedeelte ligt ten noordoosten van het FieldLab gedeelte. De figuren 5.5 en 5.6 betreffen het kraamkamer gedeelte. Een ca 80 ha groot onderdeel dat aan de Noordkant wordt begrensd door de spoorlijn

Lelystad Zwolle aan de westkant door de Swifterringweg en aan de zuidkant door de Elandweg.

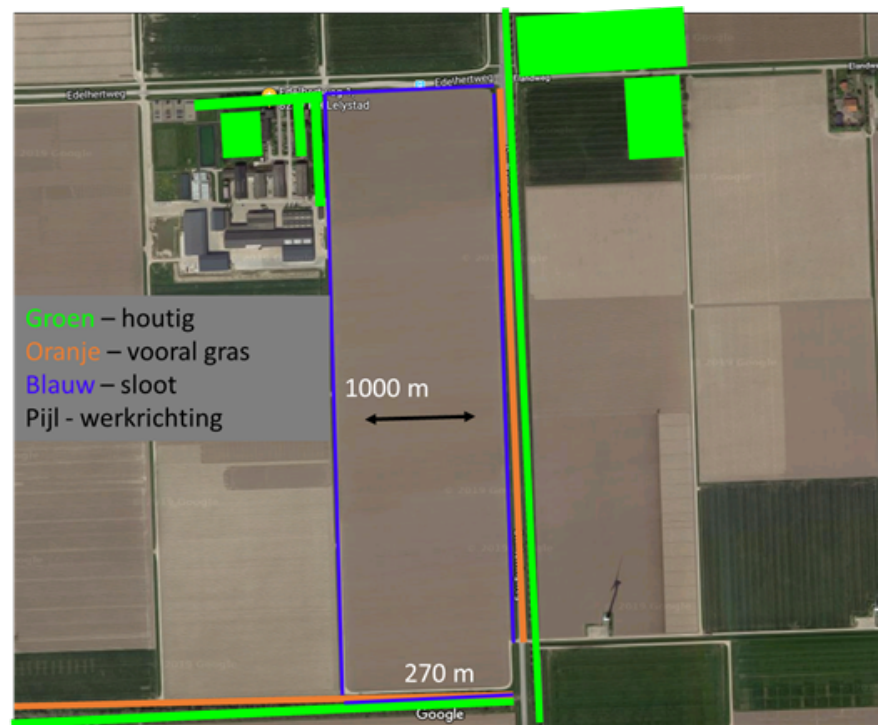

Figuur 5.5 Huidige situatie ecologische infrastructuur BvdT, gedeelte FieldLab (ca. 30 ha).

De figuren 5.5 en 5.6 betreffen het FieldLab gedeelte (ca $30 \mathrm{ha}$ ). Dit wordt aan de noordzijde begrensd door de edelhertweg, aan de noordwestzijde door de bedrijfsgebouwen van WR open teelten, locatie Lelystad. Aan de oostzijde is het begrenst door de Swifterringweg. Aan de zuidzijde ligt een deel van de ecologische hoofdstructuur bestaande uit een houtwal. Deze houtwal sluit in het westen van het gebied aan bij een groenstrook langs de A6 die naar het zuiden toe (onderbroken door de Runderweg) aansluiting heeft bij een deel van de Ecologische Hoofdstructuur langs de Lage Vaart (beheerder Staatsbosbeheer) en verder met het Natuurpark Lelystad (Flevolandschap).

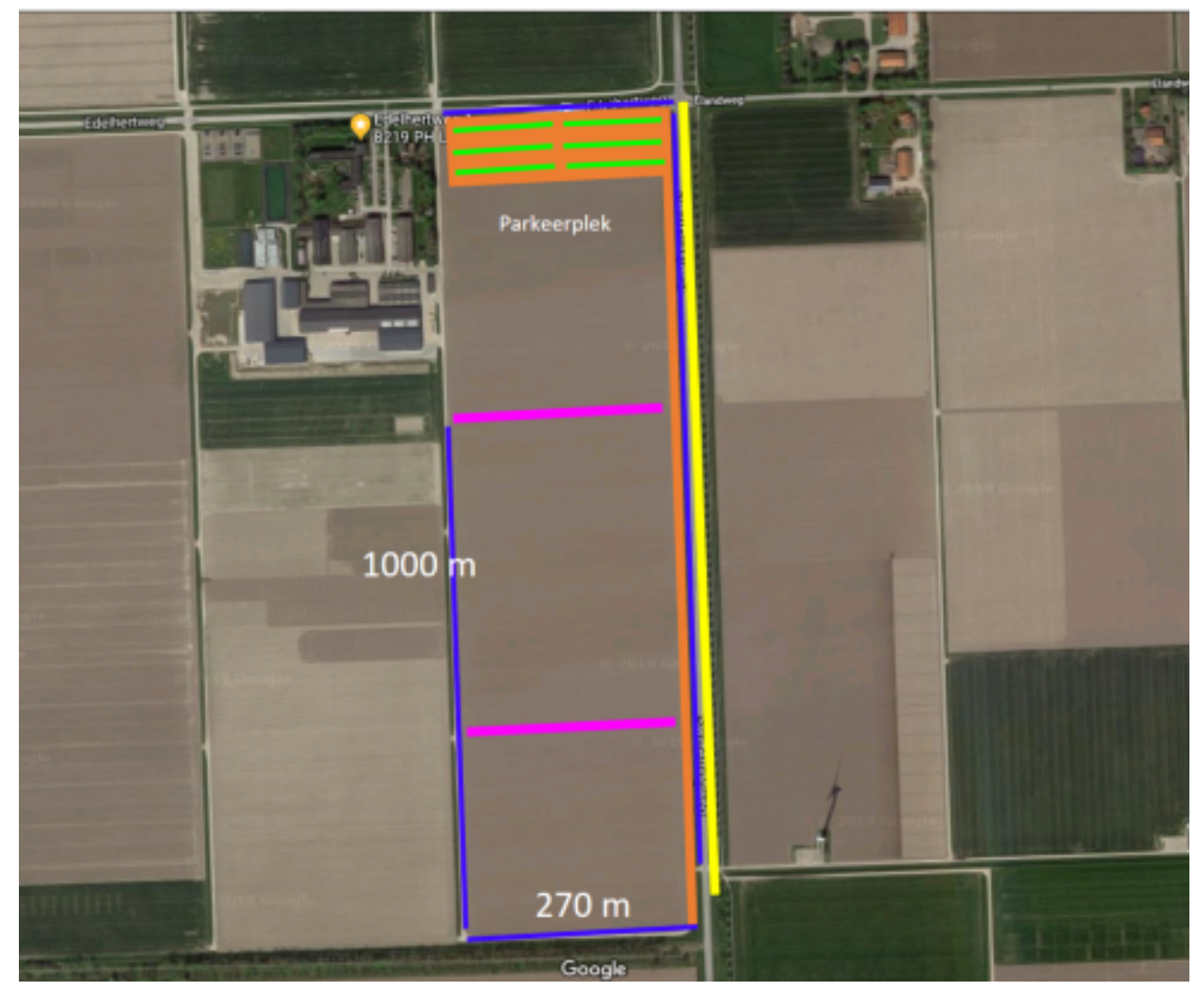

Figuur 5.6 Voorstel voor ontwerp ecologische infrastructuur BvdT, gedeelte FieldLab (ca. 30 ha). 
Figuur 5.7 geeft de inbedding van de ecologische structuur weer op het niveau van het landschap. De blauwe vakjes zijn het FieldLab en de kraamkamer. De rode stip betreft de kantoorlocatie. De twee

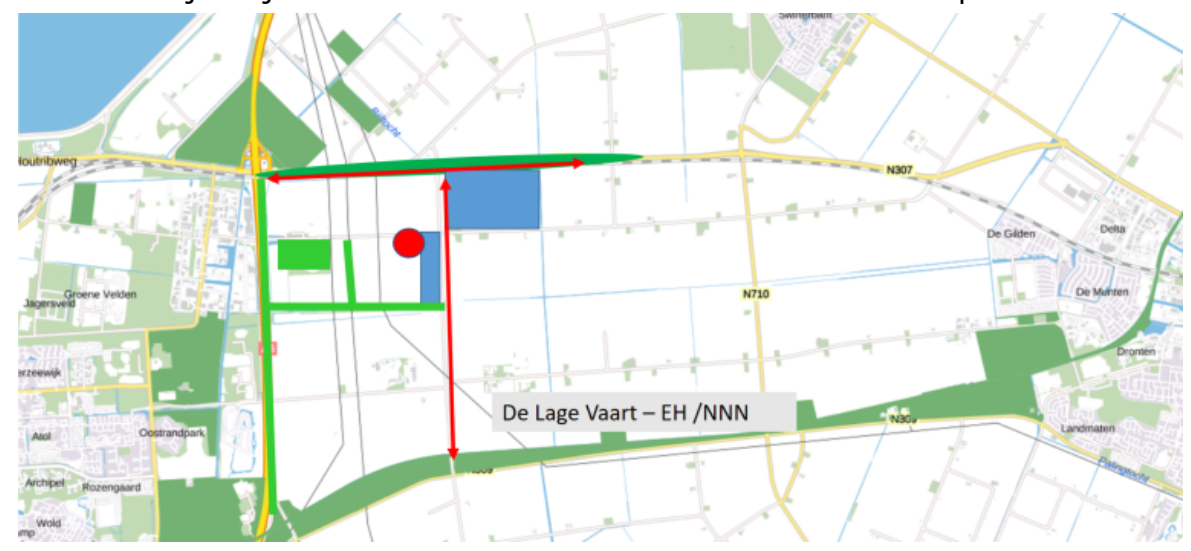
lichtgroene stroken zijn in beheer bij SBB en betreffen houtwallen met bomen en struweel. Dit sluit aan de westkant, langs de A6 aan op een groenstrook die vervolgens in het zuiden - langs de lage vaart - aan op een

Figuur 5.7 Landschappelijke ecologische infrastructuur.

bosstrook dat onderdeel is van de ecologische hoofdstructuur die Lelystad en Dronten met elkaar verbindt. En deze structuur sluit aan in het zuidwesten op het Natuurpark Lelystad. De rode pijlen in figuur 5.7 betreffen weg- en slootbermen die - eventueel met aangepast beheer - aan kunnen sluiten op de ecologische structuur in het gebied.

\subsection{Agronomie}

Het agronomisch ontwerp van de BvdT wordt hier beperkt tot het FieldLab. Het ontwerp voor de kraamkamer wordt in eerste instantie bepaald door de daar aanwezige langjarige systeemproeven. Het FieldLab bestaat in de basis uit de gewaskeuze en het (oppervlakte) aandeel van de gewassen (tezamen het bouwplan), de gewasvolgorde (vruchtwisseling), de ruimtelijke configuratie van de gewassen en de teeltwijze van de gewassen.

Voor het agronomisch ontwerp is naast de gedefinieerde doelen van de BvdT, nog een aantal andere samenhangende keuzen van belang die een rol spelen in het agronomisch ontwerp:

- Ecologie of technologie als uitgangspunt: Gebruik maken van ecologische principes is een uitgangspunt die min of meer door de opdrachtgevers is meegegeven. Technologie is een belangrijk hulpmiddel om de doelen te bereiken maar is ondersteunend aan de agro-ecologie en niet bepalend voor de agronomie en ecologie.

- Land sharing: De grond wordt gezamenlijk gebruik voor voedselproductie én voor habitat en voedsel voor invertebraten. De bevordering van biodiversteit staat mede in het teken van het weerbaar maken van het productiesysteem (functionele biodiversiteit). Er is ook ruimte voor vogels kleine zoogdieren, reptielen etc. Perceelsranden, sloten (ecologische infrastructuur) etc. bieden ruimte voor eutrofe en mesotrofe wilde flora en fauna.

- Lage bodemdruk en rijpadensysteem: mechanisatie dient een goede bodemkwaliteit zoveel mogelijk te ondersteunen. Dit betekent dat drones, sensoren, autonome voertuigen zoveel mogelijk ingezet worden. Deze technologieën zijn op dit moment nog niet altijd gecombineerd in voor de landbouw werkzame en betaalbare machines. Vermoedelijk zal de teelt van de gewassen daarom nog deels afhankelijk zijn van de klassieke mechanisatie (trekker met werktuig). Derhalve moet rekening gehouden worden met de inzet van deze landbouwmechanisatie, zij het op een manier dat ook gemakkelijk omgeschakeld kan worden naar nieuwe vormen van mechanisatie. Toepassing van vaste rijpaden met GPS systemen is daarom van groot belang.

- Toepasbaarheid voor de praktijk: Het ontworpen systeem moet toepasbaar zijn voor een grote groep telers. Eventuele nieuwe gewassen moeten voldoende marktpotentie hebben voor een brede groep telers of moeten model staan voor een grotere groep alternatieve gewassen (zoals bijv. noten in agroforestry systemen).

- Kostprijs productie: producten moeten in principe in relatief grote hoeveelheden in vaak relatief anonieme afzetmarkten vermarktbaar zijn. Dit betekent ook dat de kostprijs voor de productie niet veel hoger kan zijn dan de huidige. Mogelijk kan een deel van de meerkosten t.o.v. huidig 
terugverdiend worden door beloning van ecosysteemdiensten als biodiversiteit (zoals de bedoeling is met de Biodiversiteitsmonitor Akkerbouw) of waterbeheer of via een meerprijs van het product door bijv. certificering (via Planetproof).

- Regelgeving: Huidige regelgeving en subsidies zijn niet exclusief leidend voor het ontwerp maar kunnen wel een belangrijke rol spelen in de keuzen die worden gemaakt (bijv. regelgeving voor emissies van gewasbeschermingsmiddelen van het ene naar het andere gewas).

\subsubsection{Keuze bouwplan}

Het bouwplan is de gewaskeuze en het aandeel van de gewassen in het bouwplan. Bij de samenstelling van het bouwplan spelen o.a. de volgende aspecten een rol:

- De grondsoort.

- Het bouwplansaldo (voldoende cash crops in het bouwplan).

- Mechanisatie behoefte en arbeidsbehoefte (arbeidsfilm).

- Intensiteit/frequentie van bepaalde gewassen in het bouwplan.

- Effecten van gewassen op elkaar in ruimte en tijd (bodemgezondheid, structuureffecten, $\mathrm{N}$ overdracht, positieve of negatieve interacties tussen gewassen in ruimte).

- $\mathrm{N}$ bemestingsbehoefte en bouwplan.

- Structuureffecten van gewassen (positief en negatief).

- Bijdrage aan organische stof aanvoer bodem.

- Rekening houdend met eiwittransitie.

- Samenwerking/uitwisseling met veehouderij.

- Zoveel mogelijk jaarrond bodembedekking (incl. groenbemesters).

- Voldoende ruimte voor groenbemesters.

- Positieve of negatieve rol op biodiversiteit (bijv. aantrekkelijke gewassen voor bestuivers).

Voor draagvlak in de praktijk is het van belang om te kiezen voor afzet in relatief grote hoeveelheden (bulk) naar relatief anonieme afzetmarkten. Dit heeft als gevolg dat de keuze voor huidige cash crops als bijv. aardappel, suikerbiet, ui en peen voor de hand ligt. Vanwege de zorg voor een goede bodemstructuur kan hierbij het percentage rooivruchten in het bouwplan worden gemaximeerd op $50 \%$. Aardappel en suikerbiet kan 1 op 4, peen en ui bij voorkeur naar 1 op 6 of 1 op 8 . Naast de genoemde rooivruchten zijn er nog andere cash crops mogelijk zoals bijv. koolgewassen. Indien we erin slagen om volledig onbereden teeltbedden te realiseren (zie mechanisatie), kan het aandeel hakvruchten mogelijk omhoog (naar bijvoorbeeld 60\%)

Voor de samenwerking met veehouderij dient ook een aantal gewassen die naar de veehouderij kunnen worden afgezet, worden opgenomen. Dit kunnen ruwvoeders zijn als grasklaver of luzerne of grondstoffen voor krachtvoerders (granen, eiwitgewassen als soja, veldboon, voedererwt). Granen lijken een logische keuze vanwege de uitwisseling van stro en mest met veehouderij en vanwege positieve effecten op bodemkwaliteit. Vanuit de eiwittransitie en om de $\mathrm{N}$ behoefte in het bouwplan te verminderen, is er ook een voorkeur om voldoende leguminosen op te nemen. Ook kunnen bloeiende leguminosen een bijdrage leveren aan de aantrekkelijkheid voor bestuivende insecten. Leguminose akkerbouwgewassen als soja (droog of vers) en veldboon dienen geteeld te worden voor de humane markt om zodoende het saldo voldoende interessant te maken.

Op het perceel waar het FieldLab van de BvdT komt te liggen zijn enkele beperkingen aanwezig op gebied van bodemgezondheid. Er zijn pleksgewijs enkele haarden met lichte besmetting met Globodera pallida (2012, nieuwe bemonstering uit te voeren in 2019). Dit geeft mogelijk beperkingen in de rassenkeuze van aardappel. Daarnaast is in 2018 in de erwtenteelt stevig voetziekte opgetreden (waarschijnlijk Fusarium oxysporum), wat voor de komende jaren de teelt van erwt uitsluit. 
Op basis van bovenstaande uitgangspunten en overwegingen, wordt het volgende bouwplan voorgesteld:

- Aardappel: $25 \%$.

- Grasklaver: $12,5 \%$.

- Ui/peen: $12,5 \%$.

- Leguminose (vlinderbloemige): 12,5\% veldboon/soja.

- Tarwe $12,5 \%$.

- Suikerbiet $12,5 \%$.

- En maaigewas 12,5\% waarbij gekozen kan worden uit een tweede leguminose, koolzaad vlas, karwij of koolgewas.

\subsubsection{Keuze vruchtwisseling}

Overwegingen om te komen tot de juiste vruchtwisseling zijn: bodemgezondheid, $\mathrm{N}$ transfer van ene naar andere gewas, vermeerdering of vermindering onkruiddruk, structuur effecten en ruimte voor groenbemesters. Voor het ontwerp is dit minder relevant maar des te meer voor de verdere detailuitwerking.

\subsubsection{Ruimtelijke configuratie}

Er zijn met een bouwplan van minimaal 4 gewassen, vele ruimtelijke verdelingen van de gewassen over het perceel mogelijk zoals bijv. de klassieke benadering van 1 aaneengesloten perceel per gewas, strokenteelt of mengteelt. (zie figuur 5.8). Bij strokenteelt en mengteelt zijn er weer vele combinaties mogelijk, menging of stroken met twee gewassen (gewasduo's per perceel) tot en menging of stroken van alle gewassen. Ook combinaties van mengteelten en strokenteelten zijn mogelijk. zoals bijvoorbeeld strokenteelt van een tarwe-veldboon mengsel in combinatie met stroken van suikerbiet.

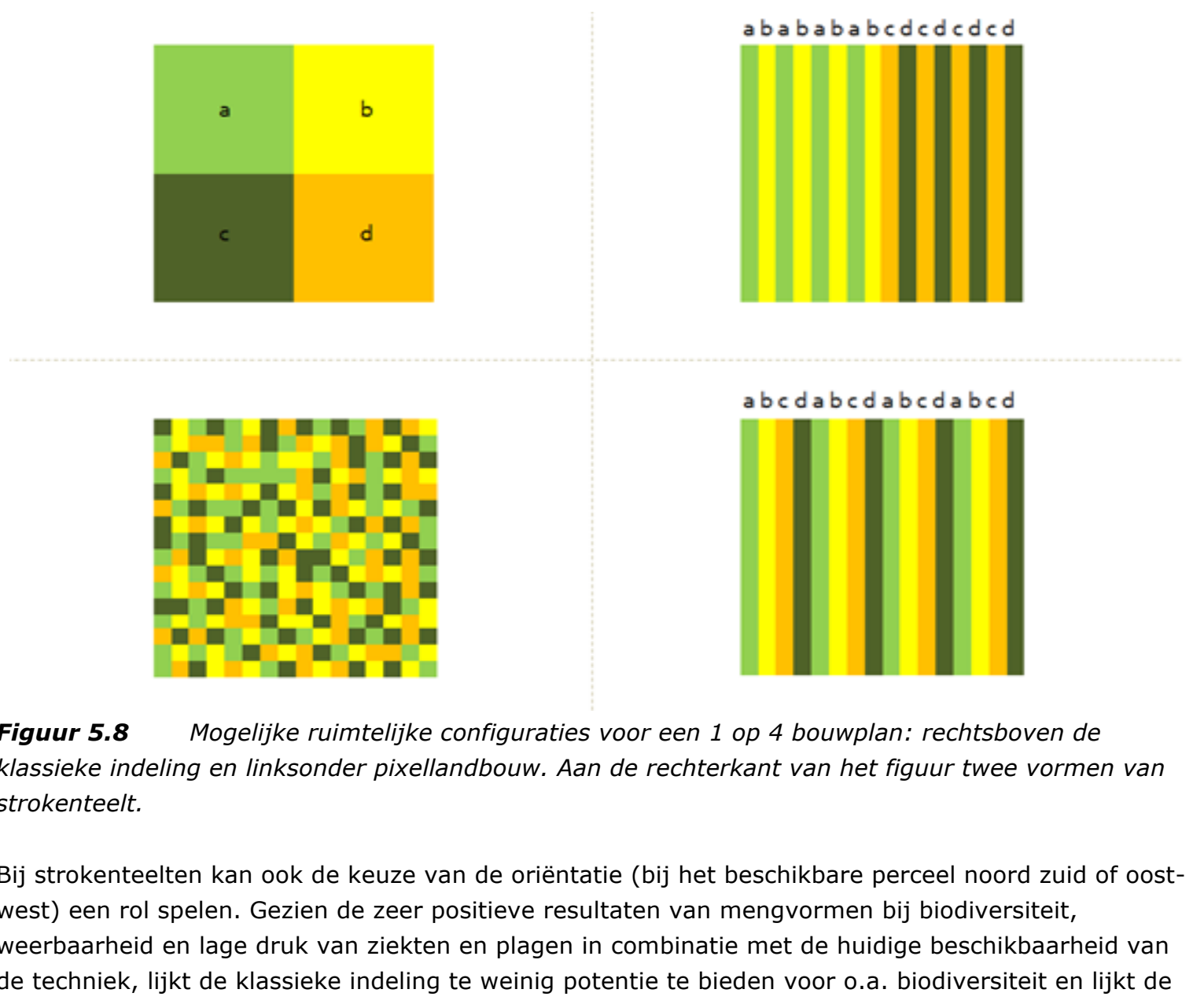


pixel teelt momenteel technisch en economisch niet haalbaar. Strokenteelt lijkt hier een mooie middenweg die op de middellange termijn ook haalbaar kan zijn voor de praktijk.

Bij strokenteelt blijven er nog vele keuzemogelijkheden over: de breedte van de stroken, per rij tot en met bijvoorbeeld spuitmachine breedte, de hoeveelheid gewassen die in stroken naast elkaar liggen en de mogelijke menging van gewassen binnen stroken (bijv. grasklaver of tarwe veldboon). Het is zelfs ook mogelijk om de ruimtelijke configuratie in de tijd te variëren (bijv. jaar 1. peen ui combi in stroken en jaar 2. volvelds tarwe).

De effecten van gewasdiversiteit via strokenteelt op met name functionele biodiversiteit en het onderdrukkend effect op de ontwikkeling van ziekten en plagen in aanmerking nemende, is het grootst bij een beperkte strokenbreedte. Het is van belang om een strookbreedte te kiezen die goed past bij een groot deel van de klassieke mechanisatie (zie paragraaf mechanisatie), maar biedt ook mogelijkheden voor toepassing van nieuwe kleinschalige en geautomatiseerde technologie. Mogelijk een aanvaardbaar compromis tussen huidige praktijk en toekomstig beschikbare technologie.

Het voorstel dat momenteel voorligt is om met twee onderscheidende breedtes van stroken te werken in combinatie met een vaste rijpadenbreedte die moet bijdragen aan betere bodemkwaliteit. Deze rijpadenbreedte is 3,15 meter (zie paragraaf mechanisatie) waaruit onbereden bedden resulteren van 3 meter. De twee onderscheidende strokenbreedtes worden 3,15 meter en 22,05 meter (dit zijn 7 rijpaden van 3,15 meter). Met deze opzet slaan we een brug tussen het ideaalbeeld van de toekomst en een format dat meer aansluit bij de huidige vorm van landbouw.

$\mathrm{Na}$ de keuze voor bouwplan en vruchtwisseling is het nog van belang een keuze te maken voor gewascombinaties. Welke gewassen komen naast elkaar te liggen of welke gewassen worden gemengd? Ook dit is een uitwerking die minder noodzakelijk is voor het ontwerp maar des te meer voor de verdere uitwerking.

\subsection{Mechanisatie}

De keuze voor een rijpadensysteem om de bodembelasting door mechanisatie zoveel mogelijk te verminderen, heeft consequenties voor de keuze voor mechanisatie. In deze paragraaf zal nader ingegaan worden op de vereiste en beschikbare mechanisatie om het bouwplan en de gekozen configuratie mogelijk te maken.

Er wordt in dit ontwerp uitgegaan van een standaard werkbreedte van $3 \mathrm{~m}$. Dit is een praktische keuze. In de huidige praktijk zijn rijafstanden van gewassen immers zodanig dat meerdere rijen altijd veelvouden van 1.5 meter zijn. Qua keuzes voor breedtes machines is een veelvoud van $1.5 \mathrm{~m}$ dus handig. In de praktijk is $3 \mathrm{~m}$ de meest gangbare breedte.

In een toekomstig ideaalbeeld van de BvdT kan het zijn dat deze werkbreedte niet ideaal is. Uiteindelijk is de ecologie leidend en is de mechanisatie daarop volgend. We kiezen binnen de BvdT echter op dit moment voor de standaard werkbreedte van $3 \mathrm{~m}$, omdat op deze afstand alle machines beschikbaar of leverbaar zijn. Dat verhoogt ook het draagvlak in de praktijk.

Bij de keuze van mechanisatie op gebied van gewicht en capaciteit moet het (beperken van) gewicht leidend zijn. De arbeidsbehoefte van het modelbedrijf wordt hierdoor in eerste instantie verhoogd, maar het is de verwachting dat gedurende de looptijd van BvdT robotisering beschikbaar komt waardoor de arbeidsbehoefte uiteindelijk zal dalen.

\subsubsection{Keuze voor rijpaden}

Uitgangspunt is om machines te laten rijden waar het 't best uitkomt. Het toelaatbare gewicht van de machines wordt bepaald op basis van wat natte grond ( $p f=2$ ) aan kan. Hoewel het lastig is een harde wetenschappelijk onderbouwde bovengrens voor gewichten (of bodemdrukken) te vinden, is de ervaring van bodemkundigen dat dit onder de 3 á 4 ton aslast moet blijven. Hierbij is aslast (of wiellast) belangrijker dan bandenspanning omdat het de ervaring is dat bandenspanning verdichting in 
de bovengrond bepaald terwijl aslast voor ondergrondverdichting zorgt. De slotsom is dat een systeem van lichte mechanisatie en random traffic (dus geen rijpaden) met de huidige techniek niet mogelijk is zonder te hoge aslast. Alle mechanisatie (ook die van 30 á 40 jaar ouder) is te zwaar. Daarom moet voor rijpaden worden gekozen.

\subsubsection{Controlled Traffic Farming (CTF)}

Eén van de mogelijke scenario's is een keuzen van vaste rijpaden (Controlled Traffic Farming, CTF) op $150 \mathrm{~cm}$. Deze rijpaden liggen midden in de $3 \mathrm{~m}$ werkbreedte. Alle machines rijden op de $150 \mathrm{CTF}$. Tussen de gewasrijen wordt geen rijpad vrijgemaakt dat exclusief bestemd is om te rijden. Indien nodig wordt een uitzondering gemaakt voor een ultra licht schoffelvoertuig. Schoffelen gebeurt immers alleen als de grond droog en draagkrachtig is. Een ultralicht voertuig veroorzaakt dan geen diepe bodemverdichting. Onderstaande tabel is een overzicht van hoe goed de bewerking uit te voeren is met bestaande mechanisatie op de BvdT. Duidelijk is dat vooral oogstwerkzaamheden belemmerend zijn voor dit scenario. Andere werkzaamheden zijn goed uitvoerbaar.

Tabel $3 \quad$ Mechanisatie voor 150 CTF.

\begin{tabular}{|c|c|c|c|c|c|}
\hline \multirow[t]{2}{*}{$3 m+150 \mathrm{CTF}$} & \multirow[t]{2}{*}{ Grondbewerking } & \multirow[t]{2}{*}{ Zaaien } & \multirow[t]{2}{*}{ Gewasverzorging } & \multirow{2}{*}{$\begin{array}{l}\text { Oogst - } \\
\text { Rooien }\end{array}$} & \multirow{2}{*}{$\begin{array}{l}\text { Oogst - } \\
\text { Transport }\end{array}$} \\
\hline & & & & & \\
\hline Aardappel & + & + & + & $-* 3$ & + \\
\hline Suikerbiet & + & $+* 1$ & $+* 2$ & $-* 4$ & + \\
\hline Peen & + & + & + & $-* 3$ & - \\
\hline Ui & + & $+* 1$ & $+* 2$ & $-* 4$ & + \\
\hline Graan & + & + & + & $-* 5$ & + \\
\hline Grasklaver & + & + & + & + & + \\
\hline Soja/Vlinderbloemig (droog) & + & + & + & $-* 5$ & + \\
\hline \multicolumn{6}{|c|}{ *1 Zaaien mogelijk, indien direct acter zaaibedbereiding } \\
\hline \multicolumn{6}{|c|}{ *2 Uitgaande van ultra-licht voertuig niet op CTF } \\
\hline \multicolumn{6}{|c|}{ *3 Rooi unit moet uit scheef naast de machine hangen, terwijl de machine aan die zijkant geen steunwiel kan laten lopen } \\
\hline \multicolumn{6}{|c|}{ *4 Loofverwijzing en rooi unit moeten voor de eerste as gedaan worden } \\
\hline *5 Combine zou op 150 CTF moeten & ijden & & & & \\
\hline
\end{tabular}

\subsubsection{Controlled Traffic Farming (CTF)}

Een alternatief is een CTF op $315 \mathrm{~cm}$. De rijpaden liggen in deze opzet buiten de $3 \mathrm{~m}$ werkbreedte en daarmee buiten het gewas. Per bed is in deze opzet $15 \mathrm{~cm}$ ruimte voor de rijpaden. Daarmee komt de beteelde oppervlakte ongeveer $5 \%$ lager uit. Daar staat tegenover dat de voorwaarden voor gewasgroei op het onbereden teeltbed met verloop van jaren beter worden, terwijl ook verwacht mag worden dat de gewasrijen naast het rijpad een deel van het verlies compenseren (via meer ruimte voor bladgroei).

Tabel 4 Overzicht van hoe goed de bewerking uit te voeren is met bestaande mechanisatie.

\begin{tabular}{|c|c|c|c|c|c|}
\hline $3 m+315$ CTF & Grondbewerking & Zaaien & Gewasverzorging & $\begin{array}{l}\text { Oogst - } \\
\text { Rooien }\end{array}$ & $\begin{array}{l}\text { Oogst - } \\
\text { Transport }\end{array}$ \\
\hline Aardappel & + & + & + & $+? * 1$ & + \\
\hline Suikerbiet & + & + & + & + & + \\
\hline Peen*2 & + & + & + & - & - \\
\hline $\mathrm{Ui}$ & + & + & + & $+? * 1$ & + \\
\hline Graan & + & + & + & + & + \\
\hline Grasklaver & + & + & + & + & + \\
\hline $\begin{array}{l}\text { Soja/Vlinderbloemig } \\
\text { (droog) }\end{array}$ & + & + & + & + & + \\
\hline
\end{tabular}


Tabel 3 en 4 laten zien dat de inschatting is dat de mechanisatie bij 315 CTF beter uitgevoerd kan worden met bestaande mechanisatie dan bij 150 CTF. Met name bij de oogst lijken wat uitdagingen te zitten, maar de verwachting is dat dit met aanpassingen aan mechanisatie gerealiseerd kan worden. figuur 8.9 geeft het voorbeeld van aardappelen. De rijafstand is $75 \mathrm{~cm}$, dus 4 ruggen op een teeltbed van $300 \mathrm{~cm}$. De rooier rooit eerst twee ruggen en keert daarna voor de twee andere ruggen.

\section{CTF}

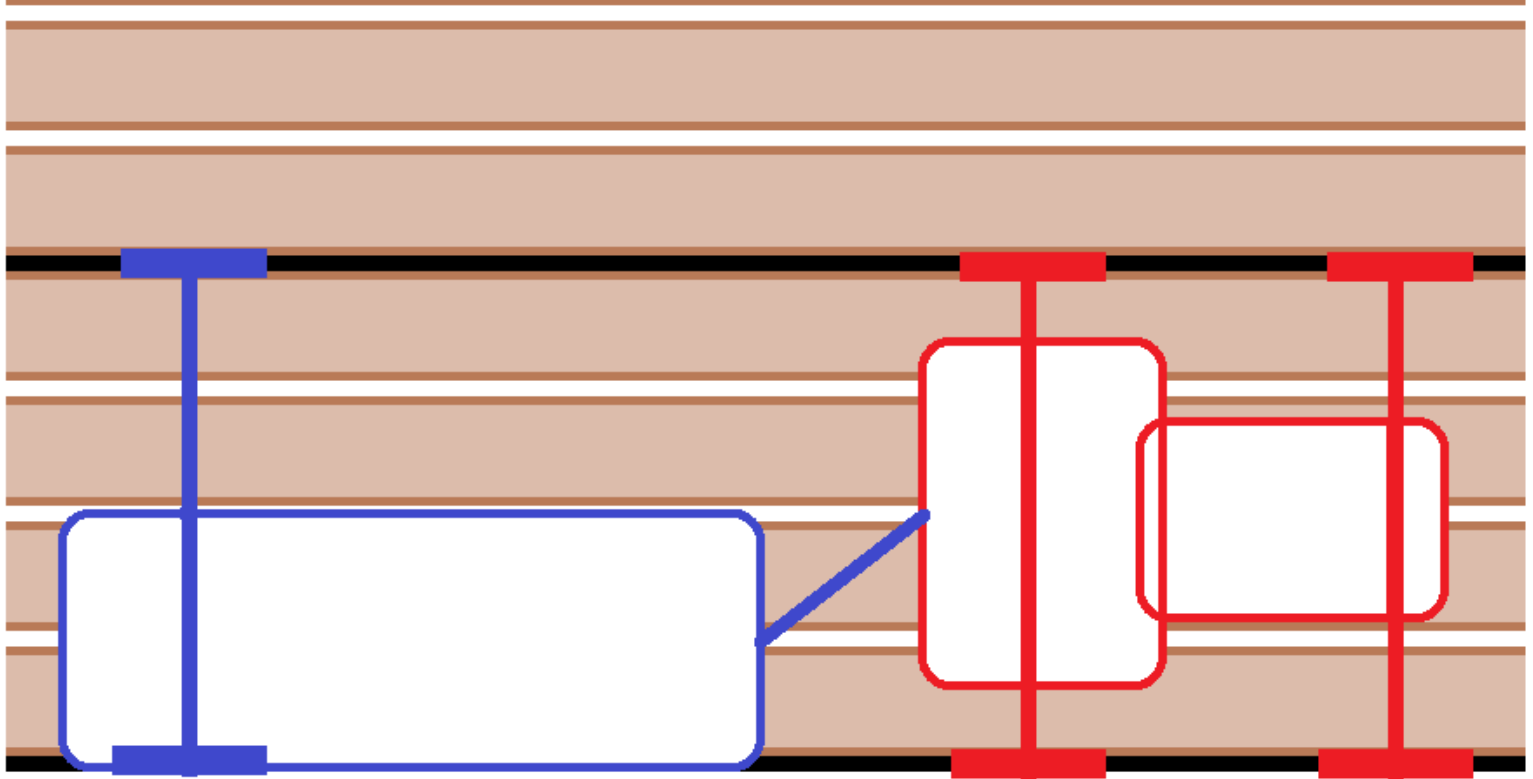

Figuur 5.9 voorbeeld van oogst aardappelen vanaf rijpaden.

\subsubsection{Ervaringen 315 CTF op BvdT}

In een deel van de proeftuin AgroEcologie en Technologie (kraamkamer, voormalige Broekemahoeve, toekomstige kraamkamer van BvdT) liggen al meer dan 10 jaar 315 CTF rijpaden. Hoewel CTF nooit het hoofddoel van de proeven was, is er wel ervaring opgedaan met de voor- en nadelen van CTF. In deze paragraaf wordt ingegaan op de ervaren nadelen en of hoe die op te lossen zijn:

- Problemen bij wegtransport (zowel breedte als rijsnelheid) zijn voor de BvdT niet relevant. Het FieldLab ligt immers tegen het erf, en de kraamkamer is via een eigen weg te bereiken. Richting de praktijk is de breedte van machines wel een issue. Echter dit geldt ook voor standaard machines. Kijkend naar de (Europese) wegenverkeerswet is het te verwachten dat alle voertuigen op de weg uiteindelijk binnen een breedte van $255 \mathrm{~cm}$ zullen moeten blijven.

- Kerende grondbewerking is uitdagender. Bij het ploegen in een CTF systeem bestaat het risico dat de verdichte grond uit het rijpad in het bed komt. Als er in dezelfde richting als de paden geploegd wordt is dit sowieso het geval. Binnen de BvdT zal echter zoveel mogelijk niet-kerende grondbewerking toegepast worden, en in de gevallen dat kerende grondbewerking toch nodig is, zal gekozen worden voor óf spitten óf een speciale rijpaden-ploeg.

- Oogsten. Het lastigste binnen een 315 CTF-systeem is de oogst vanaf rijpaden. In de praktijk wordt vanwege een gebrek aan schaalgrote, en beschikbare techniek, vaak geoogst met standaard machines die niet op deze rijpaden rijden. Echter, met betrekkelijk kleine aanpassingen aan bestaande machines zien we mogelijkheden dit toch vanaf deze rijpaden te doen (Figuur 5.9 als voorbeeld).

- Onderhoud van bedden en rijpaden. De meeste boeren die een CTF systeem hebben ervaren in het begin problemen met het vlak houden van zowel de rijpaden als de bedden. Oorzaken van het niet 
vlak blijven zijn onder andere machines die niet vlak werken, niet goed afgestelde machines, inklinking door verdichting (in rijpad). Met de jaren komt ervaring, en verdwijnen de problemen. Al blijft het vlak houden van bedden en rijpaden wel aandacht vragen.

\subsubsection{Keuze rijpadensysteem}

We komen tot de conclusie dat 315 CTF de beste keuze is voor de BvdT. Niet alleen kan het met bestaande mechanisatie het best uitgevoerd worden zonder schade aan de bodem te doen. Ook biedt het ruimte voor het testen en valideren van toekomstige ontwikkelingen, bijvoorbeeld robots. Grotere (en dus zwaardere) robots kunnen net als bestaande trekkers rijden vanaf de rijpaden, en kleinere (dus lichtere) robots, die geen bodemverdichting veroorzaken, kunnen werken en rijden waar ze willen.

Om vanaf 2020 met rijpaden te kunnen werken zijn op de BvdT wel een aantal extra machines nodig.

\subsubsection{Benodigde mechanisatie}

Een lijst is gemaakt van de machines die nodig zijn om 315 CTF uit te kunnen voeren. Dit staat in onderstaande tabel 5 .

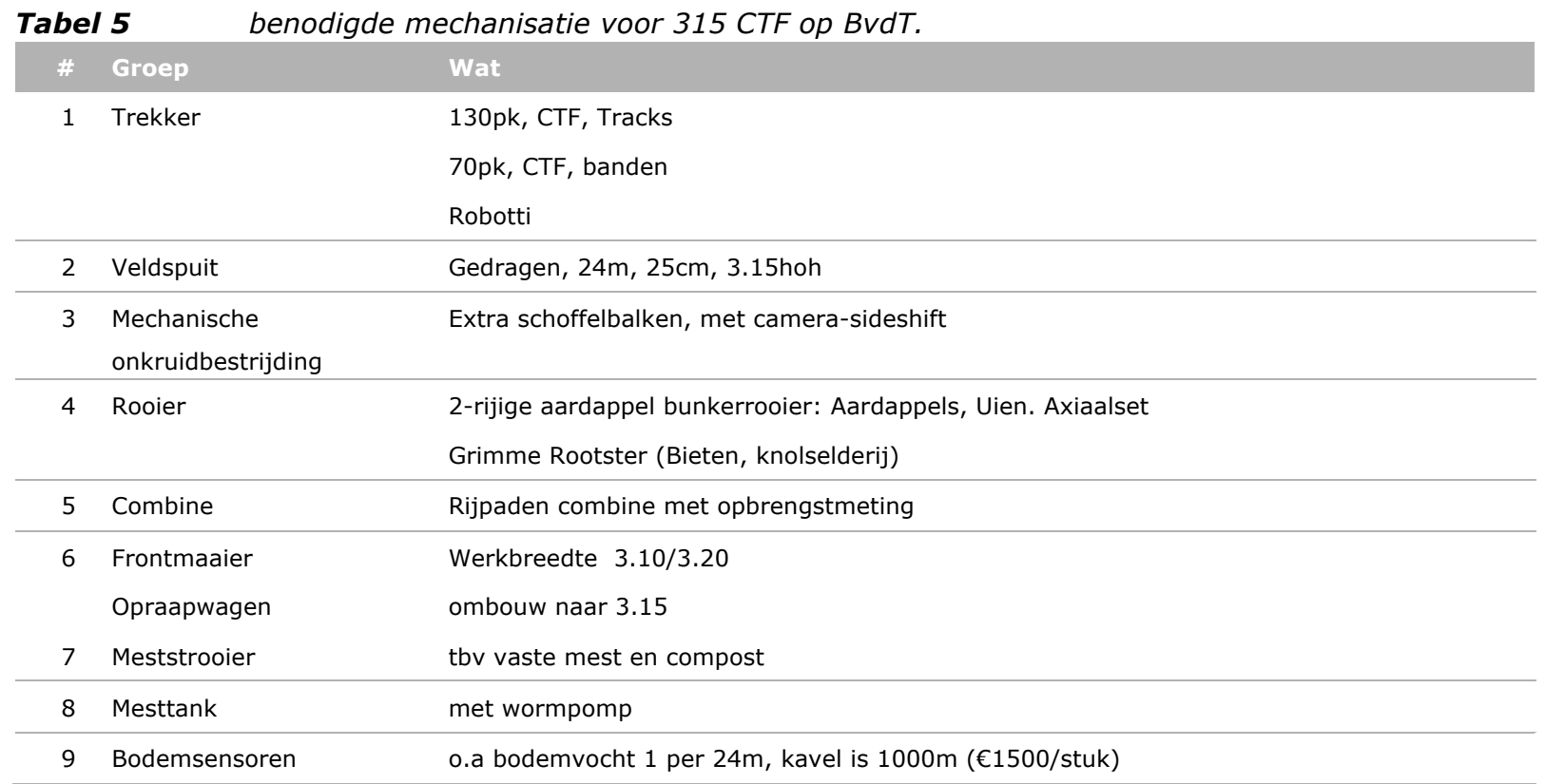

Momenteel is een rijpaden trekker van 130pk beschikbaar. Deze is volledig bezet met het werk op de huidige rijpaden op de kraamkamer en derhalve niet beschikbaar voor het FieldLab. Daarnaast zijn toepassingen als datalogging/-terugkoppeling (as-applied gegevens) niet mogelijk met deze trekker. Dit is wel een wens vanuit precisielandbouw (zie paragraaf over dit ontwerpaspect).

Voor het werk op het FieldLab zijn twee extra trekkers nodig. Eén van zo'n 130pk voor de zwaardere werkzaamheden (o.a. grondbewerking, spuiten, rooien), en één van zo'n 70pk voor de lichtere werkzaamheden. Omdat de grote van de twee trekkers vaak ook met aanzienlijke gewichten rijdt, heeft het de sterkte voorkeur dat deze is voorzien van rupsen. Voor beide trekkers geldt dat ze data van hun werkzaamheden terug moeten kunnen leveren ten behoeve van de precisielandbouw toepassingen en terugkoppeling daarop (as-applied data).

WUR beschikt met de Robotti over een robotplatform dat goed aansluit bij het ontwerp van de BvdT. De doelen van de BvdT komen ook overeen met het toekomstbeeld van de fabrikant over robotisering en de weg naar lichte en autonome voertuigen en dat onderbouwt de keuze van dit robotplatform. Hoewel het in 2020 waarschijnlijk nog te vroeg is om de Robotti een trekker volledig te laten vervangen, kan bij een aantal werkzaamheden deze robot al ingezet worden. Op deze manier kan ervaring opgedaan worden met wat robots al kunnen, en kan de BvdT zicht als testfaciliteit laten zien. 
Voor de werkzaamheden op het FieldLab is het zeer waarschijnlijk niet mogelijk de huidige Robotti hiervoor in te zetten gelet op het beslag dat andere werkzaamheden leggen op dit platform.

Op het proefbedrijf in Lelystad zijn meerdere spuiten aanwezig. Echter, geen van deze spuiten kan op 3.15 CTF paden rijden. Een goede spuit voor de BvdT heeft de volgende eigenschappen:

- Luchtondersteuning of andere driftreducerende techniek.

- $25 \mathrm{~cm}$ doppen, en per dop afsluitbaar.

- Afgifte regelbaar per sectie.

Vaste uitlijning ten opzichte van gewasrijen voor rijen-/padenbespuiting. Dit betekent dus dat de dopafstand niet altijd $25 \mathrm{~cm}$ moet zijn, maar zich elke $3.15 \mathrm{~cm}$ moet herhalen.

Vanwege de grootte van het FieldLab is het de vraag of een getrokken of zelfrijdende spuit nodig is. Een gedragen spuit volstaat waarschijnlijk ook. De gewenste tankinhoud van deze spuit is gebaseerd op een oppervlak van 30ha met een 1-op-8 rotatie. Uitgaande van een afgifte van 300l/ha betekent dit dat er 1125 liter per gewasbespuiting nodig is. Omdat de BvdT streeft naar minder bespuitingen, en meer mechanische bestrijding, is het onwenselijk een trekker het hele seizoen kwijt te zijn als spuittrekker. Snel aan-/afkoppelen moet dus mogelijk zijn. Bijvoorbeeld door Isobus aansturing en een hydraulisch aangedreven pomp.

Hieronder worden de verschillende machines nader besproken en worden oplossingen onderbouwd.

Binnen de BvdT speelt mechanische onkruidbestrijding een grotere rol dan op een conventioneel bedrijf. Om tijdig in de verschillende gewassen te kunnen schoffelen zijn voldoende schoffelbalken nodig. Hiervoor zijn 2 of 3 extra schoffelbalken nodig. Nieuwe schoffels moeten uitgerust zijn met GPS- of camerabesturing, zodat nauwkeuriger geschoffeld kan worden.

Aardappeloogst vanaf 315 CTF zou moeten kunnen door een bestaande standaard tweerijige aardappelbunkerrooier te voorzien van een verbrede as, zoals ook in figuur 5.10 zichtbaar is.

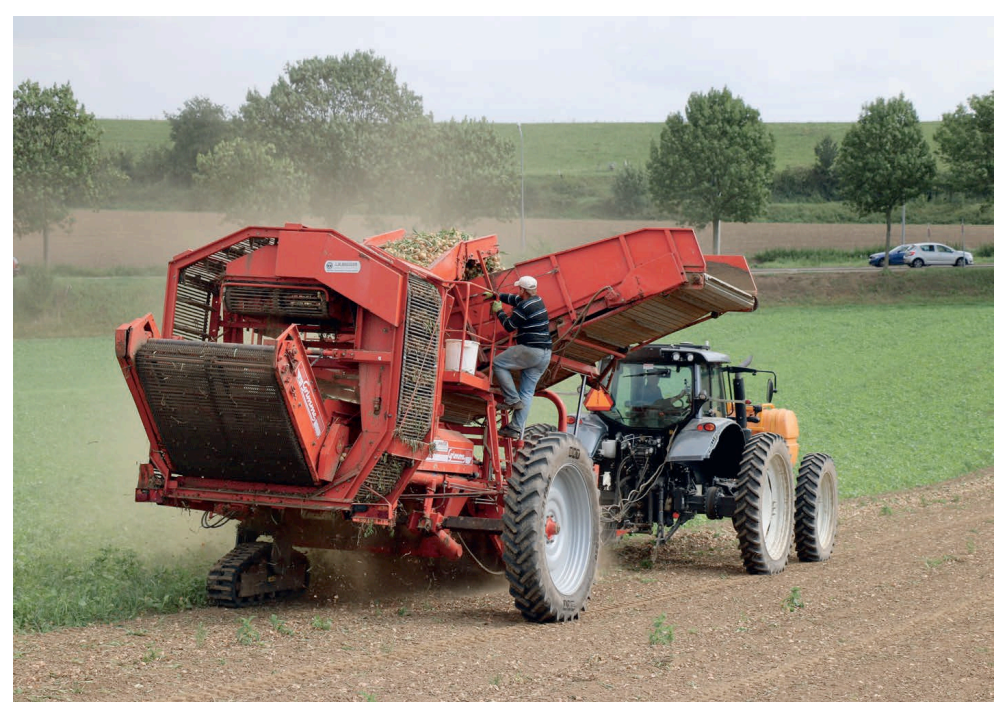

Figuur 5.10 Aardappelrooier op 315 CTF.

Om niet met kiepers in het land te hoeven rijden moet de bunker voldoende groot zijn. Hoe groot, is afhankelijk van de opbrengst. Onderstaande tabel geeft de opbrengst per werkgang voor verschillende opbrengsten per hectare en werkbreedtes. Bij een werkbreedte van $1.5 \mathrm{~m}$ is de bunker van een standaard rooier voldoende groot (vaak 6 ton of meer). Het is wel van belang te controleren dat de trekker en de verbrede as deze gewichten ook aan kunnen. 


\begin{tabular}{lrr} 
& Werkbreedte $(\mathrm{m})$ & \\
Opbrengst (t/ha) & 1.5 & 3.0 \\
\hline 50 & 2.0 & 4.1 \\
\hline 60 & 2.4 & 4.9 \\
\hline 70 & 2.8 & 5.7 \\
\hline 80 & 3.2 & 6.5 \\
\hline 90 & 3.6 & 7.3 \\
\hline 100 & 4.1 & 8.1 \\
\hline
\end{tabular}

Als bij de hierboven genoemde aardappelrooier ook een 'uien-bek' zit, kan dit ook gebruikt worden om uienzwaden te laden. Voor het rooien van uien op $3 \mathrm{~m}$ is (mechanisatie van) een loonwerker nodig.

Voor het bestaande CTF systeem op de kraamkamer is al eens gekeken of bieten (en knolselderij) vanaf rijpaden geoogst kunnen worden. Met een machine als de Grimme Rootster zou dit kunnen. Enige reden waarom dit tot op heden niet is gebeurd, is omdat de oplegdruk van de Rootster te hoog is voor de huidige rijpadentrekker. Bij een nieuwe rijpadentrekker (met nieuwere verbredingsombouw) zou dit geen probleem meer moeten zijn.

$\mathrm{Er}$ is momenteel een combine die op rijpaden kan rijden. Dit is echter een oude combine waarop geen opbrengstmeting zit. Vervanging van de huidige combine naar een nieuwere met opbrengstmeting is wenselijk in verband met de noodzakelijke dataverzameling (as-applied gegevens).

Voor de oogst van de grasklaver, en mogelijk het eiwit-gewas, is een frontmaaier nodig met een werkbreedte van iets meer dan $3 \mathrm{~m}$. Waarschijnlijk 3.20. Dit zodat er geen randjes blijven staan. De aanwezige opraapwagen moet omgebouwd worden zodat deze op 315 rijdt.

Vaste mest, compost en andere organische reststromen speelt in de BvdT een grote rol (zie paragraaf over circulariteit). Dit moet uitgereden kunnen worden. Momenteel wordt dit op de kraamkamer gedaan door een loonwerker. Hoewel de loonwerker gebruik maakt van een relatief kleine strooier op rupsen (zodat ook na het zaaien/planten bemest kan worden), gebeurd dit niet vanaf rijpaden. Indien geen enkele loonwerker hierin kan voorzien, is een eigen meststrooier op 315 nodig.

Vloeibare mest wordt nu met een sleepslang uitgereden. Naast dat dit dus niet vanaf CTF gebeurt is dit binnen smalle gewasstroken $(<24 \mathrm{~m})$ extra arbeidsintensief. Net als bij de meststrooier geldt dat als geen enkele loonwerker hierin kan voorzien, een eigen mesttank op 315 nodig is.

Ondanks dat de al het rijden vanaf de rijpaden gebeurd, is het wel belangrijk te weten hoe vochtig de grond is. Beslissingen over het wel/niet doen van bewerkingen of beregening kunnen dan gebaseerd worden op harde getallen. Deze bodemsensoren moeten hun data draadloos versturen. Te denken valt aan de sensoren van Eijkelkamp die getest zijn in het project DiSAC-Epieper. Als er elke (circa) $24 \mathrm{~m}$ een ander gewas staat, is eigenlijk ook elke $24 \mathrm{~m}$ een sensor nodig. Dit komt neer op zo'n 40 sensoren.

\subsection{Data en precisietechnologie}

Deze paragraaf gaat in op de technologie die vaak onder de noemers precisielandbouw, smart farming of data-gedreven landbouw geplaatst worden. Het gaat om o.a. sensortechnologie, digital-platform technologie, connectiviteit, artificial intelligence, robotica. We richten ons hier vooral op het FieldLab van de BvdT. Van belang is dat er voldoende sensoriek is om data vast te leggen waarmee doelen gemonitord kunnen worden en op basis waarvan waar nieuwe technologie verder ontwikkeld kan worden. De BvdT behoeft een Boer van de Toekomst aan de knoppen.

Een gross list is gemaakt van gewenste sensoren op de locatie. Daarbij ook van belang dat de data in de datakluis van de BvdT komt, en dat deze gedeeld kan worden met stakeholders. De data- 
infrastructuur zoals deze ontwikkeld is in PPS PL4.0 biedt hier een goede basis. Een overzichtelijk teeltdata dashboard waar zowel de boer als partijen op afstand mee kunnen kijken, is belangrijk. Verder van belang dat alle oogstmachines opbrengst sensoren hebben. 'Closing the data loop' qua data en aansturing is de uitdaging. Voor connectiviteit zou het goed zijn als er een 5 G mast geplaatst kan worden. Met name edge computing wordt dan een stuk eenvoudiger en dit lijkt voor de toekomst van belang. Tot slot is een aantal robot platforms en drone toepassingen nodig die een plek op de BvdT moeten krijgen. Hier dient nog een strategische keuze gemaakt te worden of er van elke soort een basis variant aanwezig moet zijn, of dat die vanuit innovatiebedrijven moet komen. In deze paragraaf hebben we een opsomming gemaakt van gewenste sensoriek, data-infrastructuur en mechanisatie. Geschatte kosten lopen snel op waarvan een groot deel structureel jaarlijks terugkomt. Dit vraagt een geleidelijk pad van verder toenemende uitrusting van de BvdT.

Over de positie van ruwvoerproductie op BvdT moet nog nader nagedacht worden. Wat hierbij kan helpen is de ontwikkeling van een digital twin. We zien met alle wensen die er zijn dat het FieldLab van de BvdT een groeiscenario moet hebben. Begin voorzichtig en laat de mate van precisie groeien per jaar. Alle wensen zullen niet in 1 keer ingevuld kunnen worden. Meerdere BvdT locaties in NL kunnen helpen bij specialisatie die gewenst kan zijn rondom deelvraagstukken.

\subsubsection{Data conform gebruikscode BO-Akkerbouw}

Hieronder een opsomming van data per informatie-categorie met daarbij specificering van data. Soms volstaat historische data. Waar relevant wordt real-time vermeld als dat een vereiste is. In laatste paragraaf staat dan een samenvatting van benodigde sensoren.

De gross list van sensoren zorgt dat ruimtelijke en temporele data data over bodemeigenschappen, klimaat in en boven het gewas, gewasgroei, -kwaliteit en opbrengst, en en teeltmanagement beschikbaar komt. Waar mogelijk wordt gewerkt met publieke data, maar in veel gevallen zal gebruik gemaakt moeten worden van sensorsystemen die op de BvdT geplaatst worden dan wel op gezette momenten ingehuurd worden.

De data infrastructuur wordt verder opgetuigd in de lijn van PPS PL4.0, waarin ieder bedrijf een eigen data ruimte heeft waarin data gestructureerd en terugvindbaar opgeslagen wordt, en van waaruit de data gedeeld kan worden met overheid, ketenpartijen en bedrijven die innovaties willen testen op de BvdT. De beheerder(s) van de BvdT (Boer van de Toekomst) krijg(en) hiertoe een specifieke training.

Hieronder volgt de genoemde gross list.

Perceelsinformatie

- Met GPS-RTK ingemeten perceelgrenzen, drainagebuizen, rijpaden systeem en andere relevante objecten (bijv. landschapselementen);

- Inpassing in basisregistraties:

- Basiskaart Grootschalige Topografie (BGT);

- Basisregistratie Percelen RVO (BRP);

- En basisregistratie landschapselementen (in ontwikkeling);

- Basis Registratie Ondergrond (BRO);

- En daarvan afgeleid relevante bodemkaart gegevens 1:50.000 en 1:10.000;

- En bodem-fysische gesteldheid;

- Luchtfoto beeldmateriaal BM4 (2019);

- Satellietbeelden Nationale Satelliet-dataportaal (2019, en verder, en terug);

- Codering en coördinaten stroken binnen het perceel.

Bodeminformatie

- Actueel Hoogte Bestand Nederland:

- AHN3 (en AHN4 zodra beschikbaar);

- Afgeleide opgaande beplanting, zoals bijv. in boomregister is verwerkt;

- Ruimtelijke variatie in kaart via bodemscans:

- Structuur variatie (zand/klei, CEC, organische stof \%) en $\mathrm{pH}$, voor wortelzone en profiel tot grondwater; 
- Bodemanalyses nutriënten:

- N,P,K, micro nutriënten wortelzone (E-lab bericht);

- Lab in de Box (LIAB) van AgroCares;

- Eventueel een nitraat-sensor e/of ander real-time sensor systeem via Eijkelkamp;

- Monsterposities met GPS vastleggen;

- Aanvullende bodem-data:

- Bodemvocht en temperatuur real-time via sensoren wortelzone;

- Bodemleven wortelzone;

- Bodem Bulk density/poriën-volume/indringingsweerstand;

- Grondwaterdynamiek, en actuele grondwaterstand op uur basis;

- Informatie over bodembewerking (strategie en uitvoering, zie management-informatie);

- Een en ander aanvullen met visuele inspecties en tellingen;

- Eventuele bijzonderheden (schaduw zones).

Oppervlaktewater-informatie

- Waterkwaliteit (monitoren emissie, o.a. fosfaat en stikstof en gbm's; nitraatsensor .....);

- Peilbeheer;

- Verzilting.

Meteorologie-informatie

- Standaard meteo parameters, Tair (meerdere hoogtes), RH, Wind (snelheid, richting, vlagen), RAD (stralingsmeter), evt. bewolkingsgraad, neerslag (mm), verdamping ETmax, ........);

- Buienradar ruimtelijke patroon metingen van neerslag;

- Evt. een reflectieve GNSS (Mistrale project) of cosmic-ray paal of drone gamma-ray sensor;

- Oppervlakte temperatuur (stralingstemperatuur) (voor energiebalans);

- Luchtkwaliteitsmetingen (NOx, NH3).

\section{Gewasinformatie}

Hieronder vallen alle gewasgroei gerelateerde gegevens. Sommigen zijn statisch, andere dynamisch in tijd en ruimte.

- Gewasrotatie is bekend (zie management-informatie);

- Hoofdgewas:

- Soort, ras en beoogde plantdichtheid;

- Monitoring gewasgroei en stadia;

- Wintergewas/catch crop/groenbemester als anders dan hoofdgewas:

- Soort(en), ras(sen) en beoogde plantdichtheid;

- Monitoring gewasgroei en stadia;

- Bewerking voor zaaien of planten van hoofdgewas;

- Gewasgroeimonitoring:

- Voor gewasgroei-monitoring dienen optische en radar beelden beschikbaar te zijn en in specifieke indices (bijv. Bioscope). Aanvulling kan via te plaatsen camera's op palen (CropView van Pessl, tarbil.com, etc.);

- Monitoring plant stress, ziekten, plagen, onkruiden via advanced sensing systemen als NPEC of Hyperspectraal+3-D faciliteit:

- Hoofdstadia gewassen waarnemen en registeren (stadium en tijdstip);

- Gerealiseerde plantdichtheid;

- Gewasgroei-data in de tijd;

- Opbrengstdata plaatsspecifiek;

- Gras vraagt om wekelijkse groeicurves, linken met GrasSignaal en andere tools.

Managementinformatie

Hieronder vallen gegevens over alle menselijke interventies die op het perceel en/of in het gewas uitgevoerd worden, volvelds of pleksgewijs. Daarbij zo veel mogelijk as-applied kaarten van machines beschikbaar hebben. Relevante is informatie over:

- Rijpaden plan via GAOS of vergelijkbaar en A-B-lijnen rijpaden;

- Grondbewerking (datum en tijd, ruimtelijke inzet, methode, instelling, brandstofverbruik, taskmap \& as-applied kaart); 
- Zaaien of planten van hoofdgewas (idem);

- Bemesting (idem);

- Onkruidbeheersing (idem);

- Gewasbescherming (idem);

- Irrigatie / fertigatie (idem);

- Oogstvoorspelling (op perceelsniveau of management zones);

- Oogsten (idem, maar dan is de output de opbrengstkaart in kg/ha en kwaliteit van het product);

- Monitoren van de voortgang: opbrengsten, economie, duurzaamheid, biodiversiteit (welke indicatoren?). Weergave in dashboard.

Dit levert een long list op van gewenste sensoren, data en monitoring op BvdT

- Open data als bodemkaarten, via een bedrijfsmanagement systeem (BMS) of service.

- Bodemscan van het perceel (minimaal met pH, CEC, Organische stof-\%, Lutum-\%, ...) (laten uitvoeren).

- Peilbuis grondwaterstand (sensoren op bedrijf).

- Bodemanalyse uitgebreid, jaarlijks (monster naar Lab, eventueel LIAB).

- Bodemsensor (temperatuur, bodemvocht,......).

- Nitraat sensor bodemvocht en oppervlaktewater (sensoren op het bedrijf, mogelijk ook andere).

- Overige oppervlaktewaterkwaliteit sensoren.

- Penetrometer (sensor op bedrijf).

- Weerstation (temperatuur, RV, Straling, bladnat, neerslag) (sensoren op bedrijf).

- Optische-data voor biomassa-groei monitoringsysteem (sensoren op bedrijf of remote sensing).

- Radarbeeld-data voor bodemvocht en gewasmonitoring.

- Data gewasgroeimodellen o.b.v. perceelspecifieke real-time data.

- Hyperspectraal camera aan drone- of robot-platform (zie NPEC of .............).

- Crop view camera's op een paal (vision, foto's, time laps).

- Handheld plantsensoren als N-testers en Fluorescentiemeters.

- NIR op drijfmest toediengsapparatuur.

- Referentie pads en calibratiesoftware voor meetsystemen.

- Weergave data op dashboard BvdT, opslaan in PL4.0 data space.

- NPEC sensoren platform 1500 euro per dag.

- Drone opname grofweg 1000 euro per dag.

\subsubsection{Welke data-infrastructuur is nodig?}

In principe is alle data op de BvdT beschikbaar en bruikbaar door derden conform data-gebruik code van BO-Akkerbouw. De basis ligt bij het bedrijfsmanagement systeem van de BvdT.

In deze paragraaf geven we aan wat er nodig is aan data infrastructuur inclusief de connectiviteit. We passen bij data ook de FAIR principes toe. En bij de data-infrastructuur gebruiken we alle relevante standaarden, zoals ISO-XML en ISOBUS.

Er zijn enkele teeltregistratie softwarepakketten op de markt. Waarschijnlijk kan met een van deze pakketten gewerkt worden en dan een koppeling gemaakt worden met een GIS platform om geo-data te managen. Hier dient nog een keuze gemaakt te worden. We willen zo veel mogelijk data openbaar maken, maar niet alle data kan openbaar zijn in een BvdT.

Componenten in de data-infrastructuur op het bedrijf, waarbij de eerste twee het hart van de BMS vormen:

- Teeltregistratie software (softwarepakket).

- GIS-data platform inclusief opslag GEO-data.

- Teeltplanning software.

- Routeplanning software.

- Toegang tot data-leveranciers (eigen data en open data).

- Toegang tot diensten-leveranciers en teeltadviezen apps.

- Toegang van BvdT data voor derden (start-ups).

- Dashboard 'performance van de Boerderij'.

- Connectiviteit:

- Draadloze verbindingen (zoals LoRa voor sensor->BMS tot 5G voor dronebeeld -> BMS en van BMS -> machine of robot; 
- BvdT als $5 G$ testomgeving, real-time datauitwisseling/streaming.

- Telematica voor communicatie bestanden tussen BMS en machines/robots (aansluiting PL4.0, Farmmaps concept (Akkerweb 3.0)).

- Machines voorbereid voor autonome toepassing en variabel doseren (Database/terminal-to-machine connectie.).

- Software voor uitlezen tractormanagement-data als brandstofverbruik.

- Machinesoftware die as applied kaarten terug leveren aan BMS.

- Data Intelligence om met minder (goede) datapunten om te gaan.

- Phenotyping database PHIS koppelen aan Farmmaps.

- Verbinden met Cubes, zoals AgroDataCube en FoodCube (BDVC).

\subsubsection{De rol van mechanisatie in datacollectie}

Mechanisatie moet in principe een hoge mate van precisie hebben (liefst voorbereid voor variabel doseren en met terug levering van as-applied kaarten). Eerste prototypes van een robot toepassing (onkruidherkenning in gewasrij en plant-specifieke, niet-chemische bestrijding) zijn inzetbaar. Met name aan mechanisatie voor inzetten van meststoffen en gewasbeschermingsmiddelen wordt hoge eis van precisie gesteld (aansturing per sectie) om variabel doseren mogelijk te maken. Verder dient de mechanisatie in staat te zijn om as-applied kaarten te produceren. Mobiele robot platforms die ingezet worden, dienen uitgerust te zijn om sensing (gewasmonitoring, stress metingen, etc.) mogelijk te maken net als decision making en actuatie (robot toepassingen die stadium TRL 6/7 voorbij zijn) in het gewas on-the-go. Denk aan Robotti, Nairo, NPEC. Oogstmachines moeten voorzien zijn van opbrengst en kwaliteitssensoren.

Speciale aandacht wordt gevraagd voor niet-chemische onkruidbestrijdingsrobot en inzetbaarheid van drones om gewaswaarnemingen (en eventueel gewasbewerkingen) te doen. Denk aan 'eigen luchthaven' of inhuren drones van WUR of van derden. Het is uiteraard van belang om rekening te houden met de Control zone (CTR) rond Airport Lelystad.

\subsection{Energie}

De BvdT heeft als doelstelling dat het een netto energieproducent is met meer energieproductie dan verbruik, ook voor inputs. Het bedrijf is energieneutraal door het jaar heen en maakt gebruik van eigen energie op basis van zon- en windenergie. Omdat agrarische bedrijven vaak in de haarvaten van onze electriciteitsnet zitten (het grid heeft hier een geringe capaciteit), kan het bij toenemende productie van duurzame energie, interessant zijn om deze electriciteit om te zetten in waterstof. Met deze energiedrager kan de onbalans tussen productie en gebruik van energie lokaal worden opgelost en kan diesel vervangen worden door waterstof als schone brandstof. Op het bedrijf wordt in de toekomst dus geen diesel meer gebruikt voor de werkzaamheden op het bedrijf waarmee emissies van CO2 en NOx worden verminderd. Het bedrijf belast daarmee ook minimaal het energienet. Dit betekent dat er in de bedrijfsvoering (mechanisatie en gebouwen / opslag) gezocht moet worden naar flexibel op- en afschakelbaar vermogen (koeling, opslag, processing etc.). Op de Boerderij van de Toekomst wordt met ingang van 2020 op kleine schaal in samenwerking met TNO al geëxperimenteerd met waterstofproductie.

De wens ligt voor om behalve zonne-energie op daken, ook AgriPV opties aan te leggen bijvoorbeeld met bifacials in bloemenstroken. Daarvoor is wel een noord-zuid bewerkingsrichting nodig. Ook kunnen andere AgriPV opties worden toegepast die de bodem beschikbaar houden voor voedselproductie (zoals verrijdbare zonnepanelen).

Activiteiten op en direct rond het erf moeten elektrisch aangedreven worden (vorkheftrucks, beregening).

De volgende acties worden opgesomd om toe te passen in de BvdT:

- Het bijmengen van waterstof $(\mathrm{H} 2)$ in diesel: eerst commerciële systemen zijn beschikbaar. Dit reduceert de roetuitstoot in beperkte mate. 
- Kleine autonome mechanisatie (robots): dit maakt elektrificatie eerder haalbaar. Past bij niet kerende grondbewerking, vaste rijpaden en strokenteelt.

- H2-productie en H2-mechanisatie zoals hierboven al beschreven. Daarnaast kan waterstof gebruikt worden om propaangas te vervangen dat ingezet wordt voor het drogen van producten en voor het wegbranden van onkruid. Ook kan gedacht aan gebruik van waterstof in een trekker, vorkheftruck of robots.

- Een alternatief voor waterstof als brandstof voor trekkers kan ook gedacht worden een elektrische trekker (Fendt e-100).

- Een tweede alternatief is het opwekken en gebruiken van methaan (Compressed Natural Gas) als transportbrandstof. Hiervoor is een vergister nodig zoals die soms gebruikt worden in de melkveehouderij of kalverhouderij. Echter, organische reststromen zijn vooral ook interessant voor hoogwaardigere toepassing en als meststof (zie circulariteit).

\subsection{Reststromen en circulatie}

\subsubsection{Afbakening en systeemgrenzen}

In de circulaire economie staat hergebruik en grondstofbesparing centraal. Vertaald naar een landbouwsysteem gaat het dan om de stofkringlopen van stikstof, fosfaat, kali en koolstof. Een akkerbouwbedrijf is onderdeel van een grotere kringloop, zoals in onderstaande figuur 5.11 schematisch wordt weergegeven. Dat betekent dat de Boerderij van de Toekomst ook maar een deel van de kringloop fysiek kan realiseren en demonstreren.

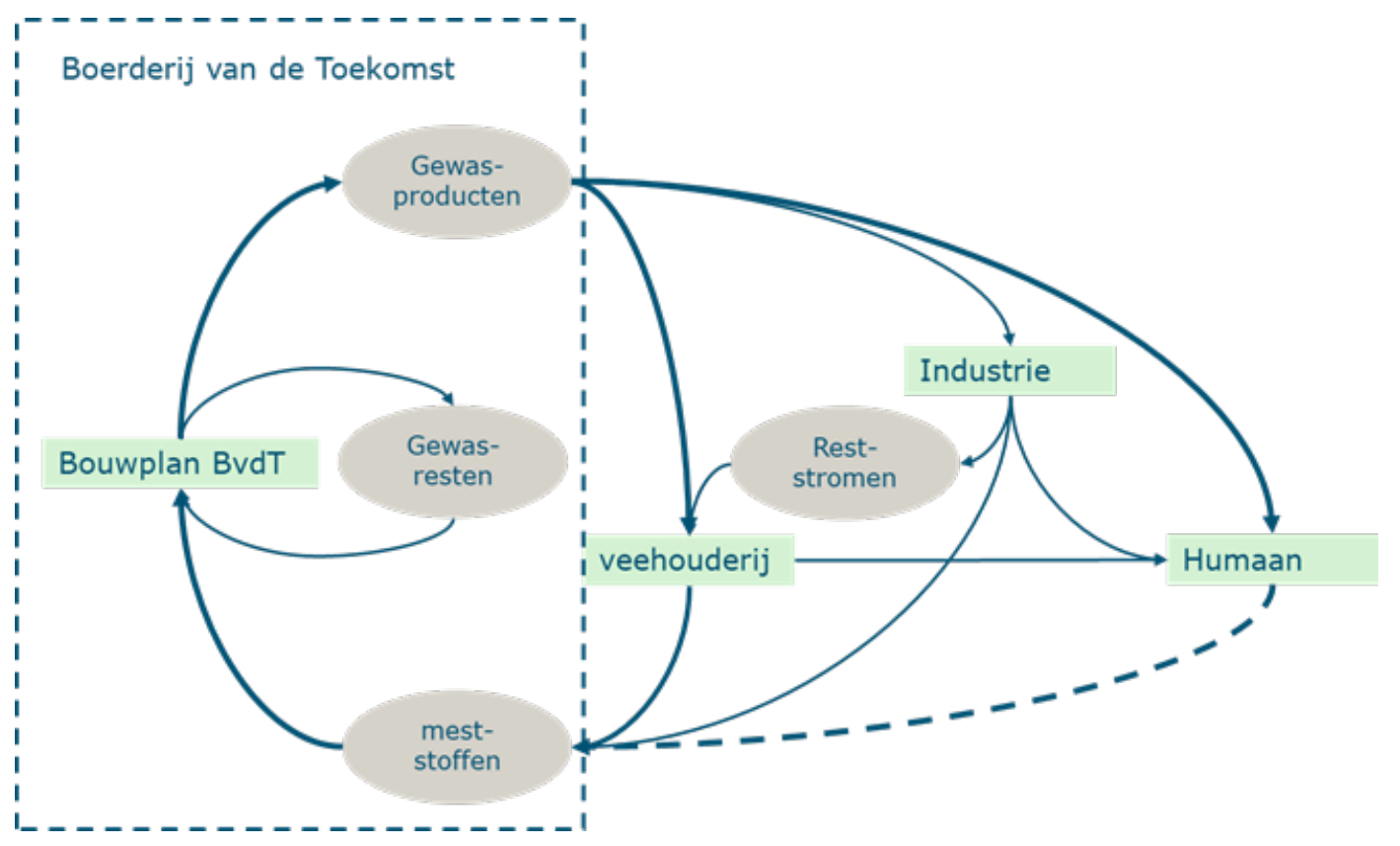

Figuur 5.11 Kringloopschema.

\subsubsection{Circulaire doelstellingen}

- De Boerderij van de Toekomst realiseert een $\mathrm{N}$-overschot op de balans van maximaal $25 \%$ om onvermijdbare verliezen te compenseren. Voor $\mathrm{P}$ is, gezien de fosfaattoestand van het perceel ( $\mathrm{PW}$ 21-24), het streven om een positieve balans van 20-30 kg per ha te realiseren. Voor $\mathrm{K}$ is de balans in evenwicht en de koolstofbalans is tenminste positief. In de uitwerking worden specifieke doelen gesteld op de reductie van emissies en het verhogen van de efficiëntie van de bemesting en de productie.

- In de Boerderij van de Toekomst staat food boven feed bij gewasproductie. De productie van veevoer is een neveneffect van voedselproductie, omdat een duurzame vruchtwisseling vaak 
(rust)gewassen bevat die niet geschikt zijn voor menselijke consumptie én omdat veel voedselgewassen bij verwerking ook reststromen opleveren die geschikt zijn als veevoer.

- In de kringloop met veehouderij, industrie en het humane systeem staat wederkerigheid centraal: de BvdT levert producten, maar vraagt daar een evenredige hoeveelheid nutriënten voor terug. Specifieker:

- De input van externe inputs wordt hierdoor geminimaliseerd, om gebruik van eindige hulpbronnen te minimaliseren.

- Daarnaast wordt voorkomen dat andere systemen worden 'gekannibaliseerd', bijvoorbeeld door onevenredig veel mest van veehouders te benutten. Dat kan namelijk alleen als de veehouder veevoer/grondstoffen van elders haalt.

- Tekorten in de aanvoer worden bij voorkeur gecompenseerd door externe circulaire stromen, zoals groene stromen uit natuurgebieden en stedelijk groen en industriële reststromen. Als het niet anders kan, wordt kunstmest gebruikt. Bij $\mathrm{N}$-kunstmest ligt het criterium bij het gebruik van duurzame energie bij de productie, i.p.v. fossiele energie.

\subsubsection{Streefbeeld}

In de Boerderij van de Toekomst wordt het gebruik van dierlijke mest en kunstmest fors lager ten opzicht van de huidige situatie in de Nederlandse akkerbouw. Daardoor geeft de BvdT een antwoord op de vraag: hoe kan een akkerbouwsysteem worden rondgezet met (veel) minder dierlijke mest en kunstmest? Deze vraag is relevant, omdat niet alleen het gebruik van kunstmest ter discussie staat, maar de kans ook bestaat dat de veehouderij in de toekomst kleiner wordt en meer grondgebonden. De inzet van humane reststromen is essentieel om deze verandering op te kunnen vangen en de kringloop te sluiten. Tegelijk is de terugwinning van nutriënten uit het humane systeem nog een enorme opgave, hoewel er wel op kleine schaal wordt geëxperimenteerd (in Bijlage 1 zijn de opties voor de BvdT uitgewerkt). De Boerderij van de Toekomst wil deze opgave agenderen en de innovatie versnellen.

\subsubsection{Bouwplan, producten en inputs}

De werkgroep Agro-ecologie stelt het volgende 8-jarige bouwplan voor: consumptieaardappelen (2x), peen, uien, graan, suikerbieten, soja en grasklaver. De producten per gewas staan in onderstaande tabel, met de gebruikelijke toepassing.

Tabel 7 Gewassen op het FieldLab en reststromen.

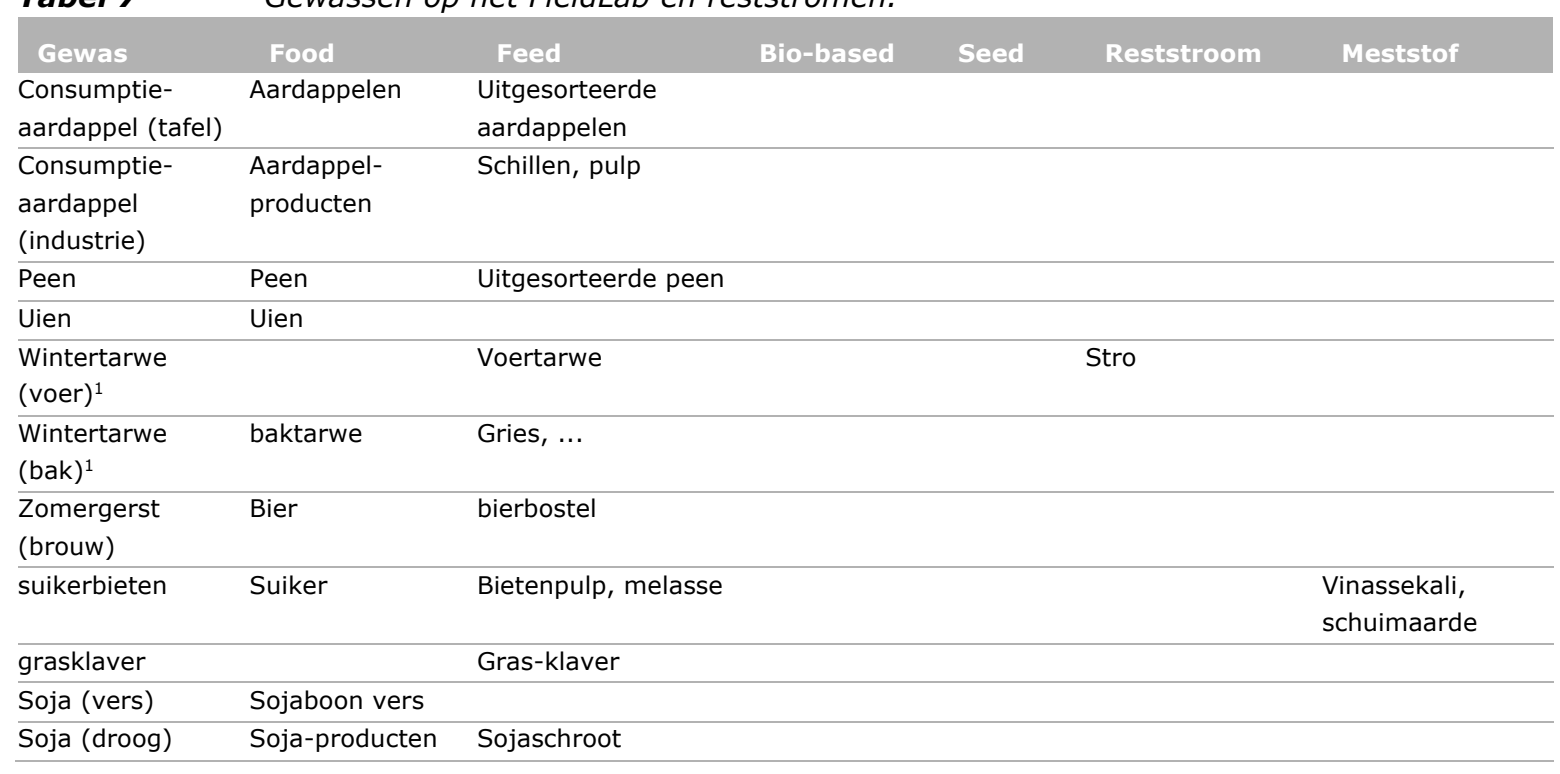

*1 In 2020 is zomergraan voorzien, omdat wintertarwe niet meer op tijd gezaaid kan worden. 


\subsubsection{Modelberekeningen}

Een eenvoudig rekenmodel is ontwikkeld om de NPK stromen in de kringloop te kwantificeren. Hoewel het model nog erg basaal is en soms wat grove aannames bevat, geeft het wel een eerste beeld van de kringloop rond de BvdT. De berekende NPK behoefte is hieronder weergegeven.

Tabel 8 benodigde nutriënten op het FieldLab.

\begin{tabular}{lrr} 
Nutriënt & Kg totaal & Kg Per ha \\
Stikstof & 4313 & 144 \\
\hline Fosfaat & 2010 & 67 \\
\hline Kali & 3263 & 109 \\
\hline
\end{tabular}

Op basis van de productie van food, feed en industriële grondstoffen kunnen de meststoffen worden gebruikt zoals aangegeven in Tabel 9.

Tabel 9

Organische minerale stromen op het FieldLab.

\begin{tabular}{|c|c|c|c|c|}
\hline & Hoeveelheid & Stikstof (kg) & Fosfaat (kg) & Kali (kg) \\
\hline \multicolumn{5}{|l|}{ Dierlijke mest } \\
\hline Rundveedrijfmest & 250 ton & 1100 & 413 & 1485 \\
\hline \multicolumn{5}{|l|}{ Industriële reststromen } \\
\hline Vinassekali & 12 ton & 40 & 4 & 26 \\
\hline Schuimaarde & 21 ton & 58 & 197 & 19 \\
\hline \multicolumn{5}{|l|}{ Humane reststromen } \\
\hline GFT-compost & 125 ton & 1113 & 550 & 988 \\
\hline Struviet & 1 ton & 18 & 272 & 0 \\
\hline Totale aanvoer & & 2328 & 1435 & 2518 \\
\hline Totale behoefte & & 4313 & 2010 & 3263 \\
\hline Tekort & & -1984 & -575 & -745 \\
\hline \multicolumn{5}{|l|}{ Invulling } \\
\hline $\mathrm{N}$ - binding gewassen & & 863 & & \\
\hline Groencompost & 200 ton & 1000 & 440 & 840 \\
\hline Balans totaal & & -122 & -135 & 95 \\
\hline Balans per kg & & -4 & -5 & 3 \\
\hline
\end{tabular}

\subsubsection{Vervolgacties voor begin 2020}

- Uitwerken bemestingsplan op detailniveau (welke producten en welke dosering?).

- Verder verfijnen van het model (m.n. de hoeveelheid reststromen bij verwerking van fritesaardappelen en zomergerst).

- Samenwerking verkennen met melkveehouder in de buurt en evt. een pluimveehouder. De contacten zijn inmiddels gelegd.

\subsubsection{Humane reststromen}

Uitgangspunten:

- NPK die de BvdT verlaten als food die in de menselijke keten belanden: aanvullen met nutriënten uit menselijke keten.

- Als hierboven maar voor feed; nutriënten aanvullen met dierlijke mest.

- Vaststellen: wat verlaat de BvdT als food en feed. Hierbij rekening houden dat wat de boerderij als food verlaat soms deels weer terugkomt als feed (bijvoorbeeld bietenpulp, bierbostel, e.d.). Dit beoordelen per gewas: bijv. suikerbieten zit geen NPK die naar mens gaan, deze komen terug als feed (bietenpulp, melasse) of meststof (schuimaarde). Bijv. peen, ui: volledig food behalve uitval. 
- Voor aanvoer organische stof (C): aparte kolom maken. Hierbij gebruik maken van kengetallen handboek bodem en bemesting.

- Afhankelijk van de afspraken met de melkveehouder, zal P naar verwachting grotendeels met dierlijke mest worden opgevuld, rest met struviet.

Mogelijke criteria voor selectie meststoffen uit humane keten

- Bron van het bemestingsproduct: excreta, voedselresten of groenafval.

- Organisch/inorganisch.

- NPK verhouding.

- Concentraties NPK (volume toe te dienen product).

- Fysische vorm: vast of vloeibaar.

- Hoeveelheid/beschikbaar voor BvdT (dus op termijn 1-3 jaar).

- Wettelijke acceptatie als meststof.

- Veiligheid, acceptabel. Wat doen we met de gewassen die geproduceerd worden met de menselijke stromen?

- Opschaalbaarheid, wat kan het op langere termijn betekenen.

Shortlist meststoffen uit humane keten die waarschijnlijk voldoende voldoen aan bovengenoemde criteria:

- Pelletized fertilizer NPKS 7:2:5:5 made from dried digestate, ammonium sulfate, struvite and potassium chloride. Van Zweeds bedrijf Ekobalans.

- Granulated fertilizer NPKS 14:2:10:14 from ammonium sulfate, struvite and potassium chloride. Van Zweeds bedrijf Ekobalans.

- (NH4)2SO4 van GMB. Uit zuiveringsslib, ammoniak dat vrijkomt tijdens compostering wordt ingevangen in zwavelzuur. Zou zich lenen voor N-bemesting granen (geen $\mathrm{P}$ en $\mathrm{K}$ nodig).

- Struviet, welke van de vele? Als demostof, is al veel over bekend, relatief schoon. Bevatcirca $20 \%$ P. Stel dat we in eerste instantie ervan uitgaan van de fosfaatbemestingsruimte (60 kg P2O5 per ha) 10-15 P2O5 wordt gebruikt voor struviet (rest met dierlijke mest). Dat betekent een aanvoer van 4$7 \mathrm{~kg} \mathrm{P} / \mathrm{ha}=40-70 \mathrm{~kg}$ struviet/ha. Bij een bedrijf van 30 ha betekent dit 1200-2100 kg struviet( $1-2$ ton.

- Slootmaaisel van waterschap Zuiderzeeland; natte stroom, wat gebeurt er nu mee? Andere organische stromen, zoals bermmaaisel. Het gebruiken van deze stromen past in het circulaire concept: immers slootmaaisel bevat deels nutriënten die uitgespoeld zijn van landbouwgrond. Met bermmaaisel is nutriënt naar de keten terug te brengen waarmee lekken deels gecompenseerd kunnen worden. Vraag is wel hoe deze stromen terug te brengen en welke tussenstappen nodig/zinvol zijn, bijvoorbeeld vergisten of composteren. vergisten, daarna digestaat gebruiken. Bij vergisten zou de vergister van Accres kunnen worden gebruikt(?). Aandachtspunt bij vooral bermmaaisel is de verontreinigingen die meekomen (zwerfvuil, zware metalen, e.d.).

- Compost van Orgaworld van droge vergisting (Biocel). Wordt nu al gebruikt in de landbouw, minder innovatief. Valt te overwegen. Bij compost spelen verontreinigingen (o.a. glas, plastic) een rol bij de acceptatie.

Meststoffen die mogelijk interessant zijn voor BvdT in latere jaren, maar waar nog vragen zijn mbt genoemde criteria

- Menselijke urine, evt eerst $P$ eruit halen (P-meststof en NK-meststof). Een issue kan natrium zijn. Te veel natrium heeft negatief effect op bodemstructuur op kleigrond. Anderzijds worden bepaalde gewassen, zoals suikerbiet soms bemest met natrium.

Meststoffen waarbij nog veel vragen zijn rond de genoemde criteria, maar die mogelijk interessant voor de experimenteerruimte binnen BvdT

- Zwart water, al dan niet vergist, bijv. uit project Amsterdam.

- Rejectiewater rwzi. Dit is een natte stroom die ontstaat na ontwatering van vergist slib.

- Effluent van rwzi. Zou kunnen worden gebruikt als irrigatiewater (bijvoorbeeld via infiltratie in de grond, nutriënten komen dan gelijk mee). Vereist wel infrastructuur (leidingen, e.d.), kostenaspect belangrijk. Geen rwzi direct in de buurt van BvdT.

- Feces compost van Fedde Jorritsma, beschikbaarheid: circa 20 m3 compost op jaarbasis.

- Calcium fosfaat, uit vergister zwart water. 
- Biogranulaat GMB, gecomposteerd zuiveringslib.

Het gebruik van gecomposteerd zuiveringsslib lijkt niet geschikt. Dit vanwege de aanwezige verontreinigingen (o.a. PFAS). Slibs afkomstig van separaat verzamelde humane excreta (feces, urine + feces) zijn schoner (nog wel medicijnresten) en lijken op termijn meer geschikt. Deze zijn ook hierboven reeds genoemd.

\subsection{Verdienmodellen}

\subsubsection{Achtergrond}

Deze paragraaf gaat in op het ontwerpaspect van 'verdienmodellen en korte ketens'. Doel van de startnotitie is om expertise en ideeën van verschillende collega's en partijen te verbinden rond dit deelthema.

Verdienmodellen: definitie De wijze waarop een organisatie of bedrijf geld verdient, noemen we het verdienmodel of het business model. Het businessmodel beschrijft kort en krachtig hoe een organisatie waarde creëert, levert en behoudt (gericht op continuïteit). Simpel gesteld: hoe een bedrijf zijn activiteiten heeft georganiseerd en klanten c.q. afnemers van dienst is. Een verdienmodel houdt rekening met zowel de opbrengstenals de kostenkant van de business

Korte ketens: definitie

Binnen de Europese Unie heeft de korte keten vaak als kenmerk "nul tot één schakel tussen producent en consument" zoals blijkt uit artikel 11 Commissie (C2014 1460), wat een toelichting biedt bij artikel 35 lid 10 Regulation (EU) No. 1305/2013. Op basis van deze definitie kunnen veel ketens niet als korte ketens worden aangemerkt. Deskundigen pleiten evenwel voor een meer inhoudelijke definitie van korte ketens, waar kenmerken als transparantie, rechtvaardigheid en partnerschap een grote rol spelen (EIP Focus Group SFSC, pagina 6). Volgens deze meer dynamische definitie zijn er meer ketens waarvoor het korte keten perspectief relevant is.

Het ontwerp van de BvdT bestaat uit een kraamkamer en een FieldLab als model voor een toekomstig akkerbouwbedrijf. Op de proeflocatie staan agro-ecologie en technologie centraal waarbij er naast de 'technische' (agro-ecologie, technologie, kringloop, energie) ook een sociaaleconomische uitdaging ligt. Deze omvat meer dan enkel verdienmodellen. Het gaat ook om maatschappelijk draagvlak peilen en invullen.

\subsubsection{Context van transitie}

Het ontwerp van de BvdT is prestigieus. Om de prestige beter waar te maken dient binnen het project ook ruimte gecreëerd te worden om de externe omgeving (waarmee ook telers in toenemende mate te maken hebben) actief bij het project te betrekken (zie paragrafen governance en interactie). Deze interacties met stakeholders kunnen gebruikt worden om te bouwen aan transitiepaden. Dit kan de uitrol van kringlooplandbouw verstevigen.

Van belang is om hierbij diverse partijen (ketenpartijen, Ngo's, burgers en consumenten/consumentenorganisaties, retail, etc.) te betrekken, waarmee de maatschappelijke betrokkenheid wordt vergroot.

\subsubsection{Transitie als proces}

In het grote geheel van 'landbouw, maatschappij en beleid' past het concept 'Boerderij van de Toekomst' in een transitieproces naar een andere vorm van landbouw, samengevat als een 'natuurinclusieve kringlooplandbouw'. Voor de landbouwsector liggen verschillende maatschappelijke uitdagingen op tafel die voortkomen uit de spanning die intensieve landbouwmethoden opleveren in 
relatie met doelen op het gebied van natuur en landschap, biodiversiteit, milieu (water, lucht, grond), voedselkwaliteit en -veiligheid. Voor het bereiken van dergelijke doelen is aanpassing van landbouwsystemen en bedrijfsmanagement dikwijls noodzakelijk. Dergelijke aanpassingen zijn soms technisch-innovatief van aard en zijn onderwerp van onderzoek en ontwikkeling. Veel doelen vragen echter ook om een systeembenadering. Technische innovaties brengen kosten met zich mee; systeemaanpassingen brengen daarnaast ook veel onzekerheid met zich mee. Beide typen aanpassingen moeten experimenteel getoetst worden en vervolgens toegepast op praktijkschaal, zoals op de BvdT. Er is echter pas sprake van een transitie als die systeemverandering uitgerold wordt via 'innovators', 'early adopters' en 'majority'.

Een dergelijke uitrol kan alleen tot stand komen als niet alleen het bedrijfssysteem verandert maar het gehele sociaaleconomische systeem in dezelfde richting beweegt. Anders gezegd, er is niet alleen verandering in de 'mindset' van boeren nodig, maar ook van alle partijen om hen heen, zoals toeleverende bedrijven (gewasbescherming, mest- en brandstoffen, landbouwmechanisatie, ICT, managementsystemen) en hun vertegenwoordigers, afnemende ketenpartijen (private of coöperatieve handels- en verwerkingsbedrijven), retail en consumenten, kennis-, scholings- en adviesorganisaties en ontwerpers en handhavers van regelgeving en beleid. Daarom is 'transitiemanagement' in feite 'stakeholdermanagement'. Anders gezegd, de verantwoordelijkheid ligt niet alleen bij de boeren maar bij alle betrokken partijen samen. Het gewenste transitieproces vraagt dan ook om een adequaat procesontwerp. Een aanpak als 'reflexief interactief ontwerpen' (zie bijvoorbeeld https://transitiepraktijk.nl/nl/experiment/method/reflexief-interactief-ontwerpen-rio) kan in een dergelijk proces helpen om tot breed gedragen ontwerpen te komen.

In dit ontwerprapport hebben we ons beperkt tot economische aspecten van veranderingen op het agrarische bedrijf, vanuit het besef dat er voldoende inkomen op het agrarische bedrijf moet worden verdiend om het bedrijf te kunnen blijven voortzetten en de benodigde aanpassingen te kunnen financieren. Vanuit het grotere concept van transitie- en stakeholdermanagement is het aan te bevelen om deze studie t.z.t. uit te breiden met een breder en interactief proces met andere partijen. Dit is een taak voor de werkgroep "Transitie, communicatie en interactie" zoals die gaat functioneren bij de start van de BvdT. Systeemveranderingen kunnen in vergelijking met onderstaande nog tot heel nieuwe ideeën leiden, al is wel een aanzet gedaan voor 'out of the box'-ideevorming.

\subsubsection{Wat betekent 'transitie' voor BvdT?}

In BvdT kunnen we niet het gehele transitieproces, dat wil zeggen landbouwbreed, vormgeven. We moeten ons beperken tot enerzijds experimenten in het FieldLab en anderzijds scenariostudies om de breedte van bijvoorbeeld verdienmodellen te verkennen en vorm te geven. Hierin staan centraal:

- Sterker incorporeren van kringlooplandbouw in het FieldLab;

- Ontwikkelen van nieuwe verdienmodellen op basis van het ontworpen bedrijfssyteem op twee sporen:

- Het spoor van ecosysteemdiensten, daarbij gebruik makend van KPI's Kringlooplandbouw en de Biodiversiteitsmonitor Akkerbouw;

- Het spoor van productverwaarding op bedrijf en in de keten, daarbij eveneens gebruik makend van de genoemde KPI's, waar nodig aangevuld met nog te ontwikkelen andere.

- Het spoor van productwaardering op basis van gecertificeerde herkomst (tracking en tracing en block chain technologie: datapaspoort).

Voor deze sporen kunnen wettelijke en bovenwettelijke eisen geformuleerd worden, waarvoor vergoeding/beloning mogelijk is.

Het eerste spoor heeft vooral betrekking op de bedrijfsvoering, het tweede en derde spoor op opslag en vermarketing van producten, waarbij productstromen zowel fysiek als administratief te onderscheiden zijn.

In het hiernavolgende wordt een aantal scenario's nader besproken, gevolgd door een activiteitenplan voor 2020 en verder. 


\subsubsection{Financiering van de omschakeling naar kringlooplandbouw}

De uiteindelijke verwachting is dat producten van kringlooplandbouw eenzelfde kostprijs zullen hebben als de huidige gangbare landbouw omdat opbrengsten beter worden en inputs als kunstmest en bestrijdingsmiddelen omlaag. Aan de andere kant zullen investeringen nodig zijn om kringlooplandbouw mogelijk te maken op gebied van precisielandbouw, datatechnologie en mechanisatie cq robotisering. Zeker de voorlopers die als eerste omschakelen, zullen een leercurve moeten doormaken in combinatie met investeringen, die het nodig maken dat er naast de "gewone" verkoop van producten (tijdelijk) andere verdienmodellen ontstaan zoals hierboven al genoemd: ecosysteemdiensten en productwaardering (via certificering). Mogelijk kan de kwaliteit van producten worden verbeterd op gebied van de toegepaste technologie en agroecologische teeltwijze. Wellicht kan dit in de beginjaren van de transitie tot een betere prijs kunnen leiden.

De toekomst laat mogelijk zien dat de verwerking en bewerking van producten steeds dichter bij of zelfs op de boerderij plaats zal vinden (value adding at farm level, kortere keten) mede doordat de technologische mogelijkheden hiervoor toenemen en betaalbaarder worden (b.v. zuivelverwerking op de boerderij). Dit biedt b.v. mogelijkheden ook de afzet in eigen hand te nemen (niches, hoge prijzen om investering terug te verdienen). Het leeuwendeel zal echter via bestaande bulkkanalen richting consument (of feed) gaan zeker als we onze exportpositie willen behouden.

Belangrijk is steeds na te gaan of er voor innovaties die vanuit de missie gedreven worden, wel voldoende marktvraag is (burger-consument). In principe is tegenwoordig steeds meer meetbaar maar levert het ook toegevoegde waarde en voor wie? En hoe kun je informatie inzetten om het verhaal duurzame aanpak bij de consument te krijgen. Wat willen de ketenpartijen en de consument en wat vinden ze er van? Vanuit dit oogpunt is het van belang om ketenpartijen, NGO's en consumenten actief bij de BvdT te betrekken.

\subsubsection{Circulaire bemestingsproducten}

Met het oog op het sluiten van kringlopen is de mestmarkt op dit moment nog bepalend; als akkerbouwer krijg je geld toe bij afname van organische mest. Dit belemmert de aanwending van alternatieven zoals struviet en gft-compost (maar er kleven nog andere belemmeringen naast de prijs aan de inzet/gebruik van deze producten). Ook de inzet van restproducten uit de levensmiddelen industrie (b.v. bierbostel als nutriëntenbron; nu wordt bierbostel als diervoeder afgezet en heeft al een marktwaarde) als meststof is een optie (zoals beschreven in de paragraaf over circulariteit). Kosten en bemestingswaarde en ontwikkelingen op de huidige mestmarkt bepalen of e.e.a. financieel interessant kan zijn. Ook kleven er mogelijk risico's aan inzet van alternatieve voor kunstmeststoffen: chemische toevoegingen, antibioticaresten, glasscherven, en wellicht ook PFAS?

\subsubsection{Mengteelten, eiwit}

Met het oog op biodiversiteit en bodemkwaliteit zijn mengteelten als strokenteelt een optie. Risico is de mogelijk ongelijke afrijping van mengteelten. Ontmengen van de mengteeltenoogst leidt mogelijk tot extra activiteiten c.q. kosten. Dit hangt mede af van het afzetdoel. Een vraag is of bepaalde mengteelten interessant kunnen zijn voor de afzetmarkt van plantaardig eiwit b.v. als ingrediënt voor vegaburger (Unilever, Burger King) of toch niche. Interessant (met het oog op klimaatverandering) zijn mogelijk nieuwe eiwitgewassen zoals soja met een hoog eiwitgehalte en dito aminozuursamenstelling in de boon.

\subsubsection{Overzicht verdienmodellen}

Voor het ontwerp van BvdT is een spoorboekje wellicht de beste weg: van traditionele naar nieuwe verdienmodellen en uiteindelijk 'out of the box'-ontwerpen. Zie Tabel 10: in groen 'opbrengstposten', in rood 'kostenposten' of 'opbrengstdervingen'. In de kolom 'Nieuwe verdienmodellen' worden aanvullende maatregelen benoemd ten opzichte van de traditionele verdienmodellen. 
Tabel 10

\begin{tabular}{|c|c|c|c|}
\hline Opties & $\begin{array}{l}\text { Stationsnaam } \\
\text { Traditionele verdienmodellen }\end{array}$ & Nieuwe verdienmodellen & Out of the box-ideeën \\
\hline \multirow[t]{2}{*}{ Hogere productiviteit } & Opbrengstverhoging gewassen & $\begin{array}{l}\text { Opbrengstverhoging geleverde } \\
\text { producten }\end{array}$ & \\
\hline & Energieproductie, -besparing en -levering & $\begin{array}{l}\text { Energieopslag tijdens pieken } \\
\text { Energietoepassing op voorbewerking } \\
\text { producten }\end{array}$ & \\
\hline \multirow[t]{2}{*}{ Hogere productprijs } & $\begin{array}{l}\text { Verbetering kwaliteit, bijv. hogere } \\
\text { nutriëntengehaltes, efficiënte verwerking }\end{array}$ & $\begin{array}{l}\text { Hogere toegevoegde waarde na } \\
\text { voorbewerking }\end{array}$ & $\begin{array}{l}\text { Specialties in badges voor } \\
\text { wereldmarkt }\end{array}$ \\
\hline & Aansluiten bij certificaat als PlanetProof & & $\begin{array}{l}\text { Duurzaam, transparant en } \\
\text { bijzonder (bijv. streek-) } \\
\text { product }\end{array}$ \\
\hline \multirow{3}{*}{$\begin{array}{l}\text { Lagere inputs, } \\
\text { waarschijnlijk dus lagere } \\
\text { toegerekende kosten }\end{array}$} & Lager energiegebruik (m.n. diesel) & $\begin{array}{l}\text { Lager energiegebruik in de keten als } \\
\text { geheel }\end{array}$ & \\
\hline & Lager (kunst-) meststoffengebruik & Minimaal gebruik van inputs & \\
\hline & Lager gebruik GBM & $\begin{array}{l}\text { Productie eigen kunstmest met eigen } \\
\text { surplus-energie }\end{array}$ & \\
\hline $\begin{array}{l}\text { Optimalisering teelt en } \\
\text { keten }\end{array}$ & Benutting van managementinformatie & Benutting van productinformatie & \\
\hline \multirow{4}{*}{$\begin{array}{l}\text { Betaalde ecosysteem } \\
\text { service }\end{array}$} & Vergroeningspremie & & \\
\hline & Toeslag voor eco-schema & & \\
\hline & & $\begin{array}{l}\text { Wateropvang op grond met groot } \\
\text { watervasthoudend vermogen }\end{array}$ & \\
\hline & & Landschapspremie 'Mondriaanontwerp' & \\
\hline Betaalde 'overige dienst & $\begin{array}{l}\text { Bijdrage aan balans energiegebruik en - } \\
\text { productie over dag en jaar }\end{array}$ & $\begin{array}{l}\text { Kleinere behoefte aan zwaarder } \\
\text { elektriciteitsnet }\end{array}$ & \\
\hline $\begin{array}{l}\text { Interactie met nieuwe } \\
\text { stakeholders }\end{array}$ & & & $\begin{array}{l}\text { Ruimte voor extra } \\
\text { duurzaam product? }\end{array}$ \\
\hline \multirow[t]{2}{*}{ Kostenverhogende inputs } & Kosten dataverkeer/-opslag; big data & $\begin{array}{l}\text { Moderne resistente rassen, duurder } \\
\text { dan traditionele }\end{array}$ & \\
\hline & & Kosten dataverkeer/-opslag; big data & \\
\hline \multirow{4}{*}{$\begin{array}{l}\text { Hogere vaste, } \\
\text { toegerekende en } \\
\text { arbeidskosten }\end{array}$} & PL-apparatuur incl. sensoren en drones & $\begin{array}{l}\text { Geautomatiseerd registreren voor } \\
\text { certificaat }\end{array}$ & \\
\hline & & $\begin{array}{l}\text { Investeringen in apparatuur voor } \\
\text { dehydratering suikerbieten, } \\
\text { kunstmestproductie etc. }\end{array}$ & \\
\hline & $\begin{array}{l}\text { Extra arbeid en energie voor metingen en } \\
\text { data-analyses }\end{array}$ & $\begin{array}{l}\text { Extra arbeid en energie voor deze } \\
\text { processen }\end{array}$ & \\
\hline & $\begin{array}{l}\text { Extra arbeid voor verantwoording } \\
\text { certificaat }\end{array}$ & $\begin{array}{l}\text { Extra arbeid voor verantwoording } \\
\text { opgewerkte producten }\end{array}$ & \\
\hline Overige kosten & $\begin{array}{l}\text { Opbrengstderving door grondgebruik } \\
\text { natuurinclusieve elementen }\end{array}$ & $\begin{array}{l}\text { Opbrengstderving door vergroting erf } \\
\text { voor energieproductie en -opslag en } \\
\text { verwerking tussenproducten }\end{array}$ & \\
\hline
\end{tabular}

\subsubsection{Uitwerking naar verdienmodellen}

Bovenstaande overwegingen leiden tot een beeld waarbij vooral verdienmodellen de transitiekosten moeten gaan dragen. Daarom is een detailuitwerking nodig op onderstaande aspecten.

- Tonen en beoordelen van verdienmodellen $(€)$

- Tonen en beoordelen duurzaamheidseffecten (o.a. kg, mbp)

- Stepping stones in het lange termijn transitieproces ("On the way to 2050")

Dit maakt het nodig en wenselijk om op het FieldLab data te verzamelen eten behoeve van technische en economische indicatoren, zoals:

- Registraties van volume en of prijs van de geproduceerde producten: diverse aankopen, verkopen, inputs, kwaliteit, investeringen, etc. Ook inzet en uitruil van reststromen.

- T.b.v. verdienmodel: betaalde en niet betaalde kosten en opbrengsten (inclusief waardering van positieve en negatieve externaliteiten zoals CO2-vastlegging en -uitstoot)

- Presenteren showcase: Laten zien wat het aan euro's oplevert inclusief duurzaamheidseffecten (3 $\left.\mathrm{P}^{\prime} \mathrm{s}\right)$.

- Saldi, bedrijfsresultaat, duurzaamheidskengetallen 
- Kg-opbrengsten en saldi zullen naar verwachting stabiliseren (klimaateffect).

- Minder gewasbeschermingsmiddelen, mogelijk meer kosten van arbeid, mechanisatie, datahandling, adviesmodellen?

- Robuust, weerbaar systeem

- Inzet en gebruik reststromen

- Beoordelen keurmerkwaardigheid van het systeem: voldoet het b.v. aan PlanetProof en hoe scoort de BvdT op de KIP's en de Biodiversiteitsmonitor Akkerbouw? 


\section{Bijlage 1 Betrokken organisaties}

Dit project is opgepakt vanuit Wageningen Plant Research en dit instituut is hieronder dus niet verder vermeld.

\begin{tabular}{|c|c|}
\hline Werkgroep & Experts en stakeholders \\
\hline Netwerk & $\begin{array}{l}\text { Groenpact } \\
\text { LTO } \\
\text { Dutch Digital Delta } \\
\text { Coöperatie Flevolands Agrarisch Collectief } \\
\text { Investerings- en Ontwikkelmaatschappij voor Noord-Nederland } \\
\text { AgriFood Tech platform } \\
\text { Provincie Noord Brabant } \\
\text { Provincie Flevoland } \\
\text { LNV } \\
\text { Akker van de Toekomst } \\
\text { Branche Organisatie Akkerbouw }\end{array}$ \\
\hline Agroecologie & $\begin{array}{l}\text { WU Farming Systems Ecology } \\
\text { WU Soil Biology } \\
\text { Aeres Hogeschool } \\
\text { Flevolandschap } \\
\text { RUG } \\
\text { Stichting Akker van de Toekomst } \\
\text { LNV }\end{array}$ \\
\hline Technologie & $\begin{array}{l}\text { Agrarisch ondernemers } \\
\text { TNO } \\
\text { TU Eindhoven en TU Delft } \\
\text { Wageningen Environmental Research } \\
\text { NPPL stuurgroep } \\
\text { Provincie Flevoland (FoodCube Almere) } \\
\text { HBO (Aeres, HAS) } \\
\text { WU-leerstoelgroepen } \\
\text { NLR } \\
\text { Wageningen Livestock Research }\end{array}$ \\
\hline Gebruik reststromen, kringlopen & $\begin{array}{l}\text { LEAF } \\
\text { WU Animal Production Systems } \\
\text { Wageningen Livestock Research }\end{array}$ \\
\hline Energieproductie en gebruik & $\begin{array}{l}\text { Agrarisch ondernemer } \\
\text { TNO } \\
\text { Wageningen Environmental Research } \\
\text { Wageningen Livestock Research }\end{array}$ \\
\hline Verdienmodellen & $\begin{array}{l}\text { Wageningen Economics Research } \\
\text { WU Urban Economics }\end{array}$ \\
\hline
\end{tabular}




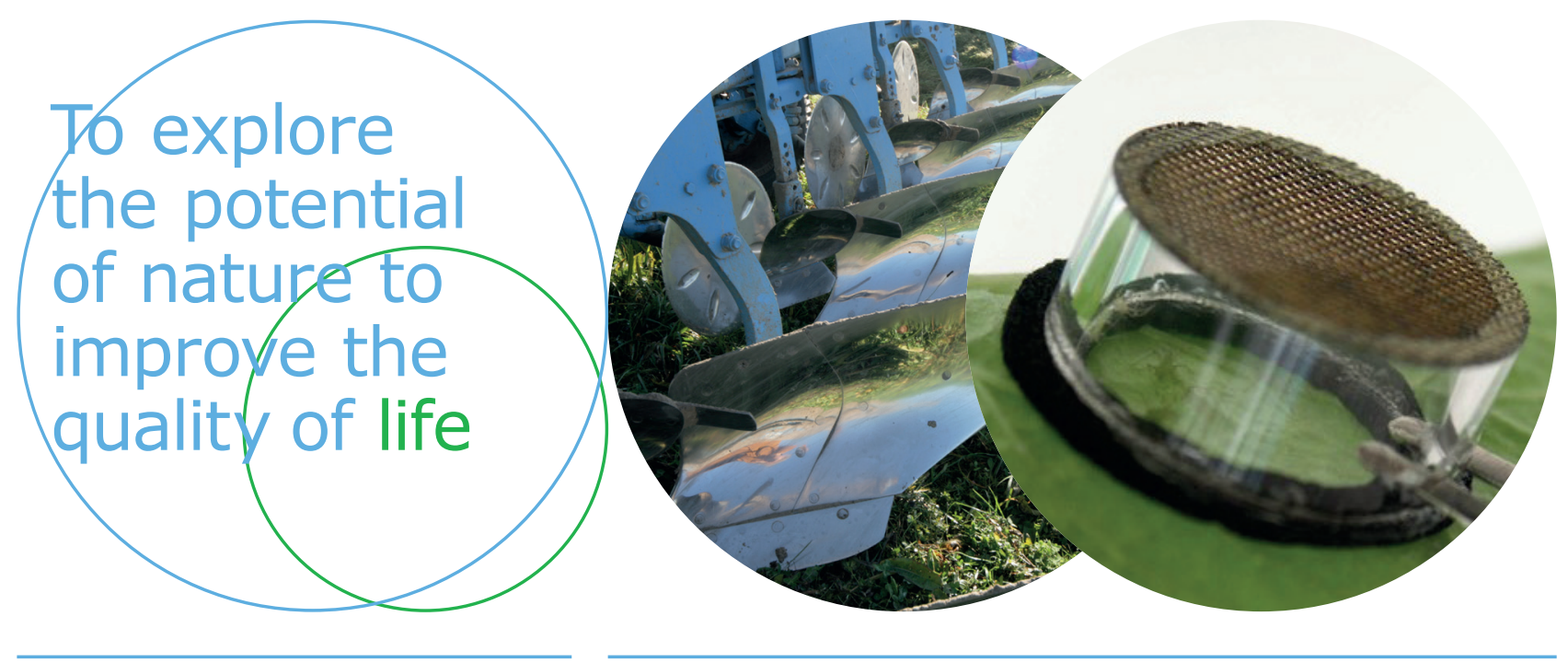

Wageningen University \& Research

\section{Open Teelten}

Edelhertweg 1

Postbus 430

8200 AK Lelystad

T (+31)320 291111

www. wur.nI/openteelten

Rapport WPR-823
De missie van Wageningen University \& Research is 'To explore the potential of nature to improve the quality of life'. Binnen Wageningen University \& Research bundelen 9 gespecialiseerde onderzoeksinstituten van stichting DLO en Wageningen University hun krachten om bij te dragen aan de oplossing van belangrijke vragen in het domein van gezonde voeding en leefomgeving. Met ongeveer 30 vestigingen, 6.000 medewerkers en 9.000 studenten behoort Wageningen University \& Research wereldwijd tot de aansprekende kennisinstellingen binnen haar domein. De integrale benadering van de vraagstukken en de samenwerking tussen verschillende disciplines vormen het hart van de unieke Wageningen aanpak. 